\title{
A Brief Overview on Antioxidant Activity Determination of Silver Nanoparticles
}

\author{
Zdenka Bedlovičová $^{1, *}$, Imrich Strapáč ${ }^{1}$, Matej Baláž ${ }^{2}$ 迥 and Aneta Salayová ${ }^{1}$ \\ 1 Department of Chemistry, Biochemistry and Biophysics, Institute of Pharmaceutical Chemistry, \\ University of Veterinary Medicine and Pharmacy, Komenského 73, 04181 Košice, Slovakia; \\ imrich.strapac@uvlf.sk (I.S.); aneta.salayova@uvlf.sk (A.S.) \\ 2 Department of Mechanochemistry, Institute of Geotechnics, Slovak Academy of Sciences, Watsonova 45, \\ 04001 Košice, Slovakia; balazm@saske.sk \\ * Correspondence: zdenka.bedlovicova@uvlf.sk; Tel.: +421-915-986-748
}

Academic Editors: José Pinela, Lillian Barros and Maria Ines Dias

check for Received: 16 June 2020; Accepted: 12 July 2020; Published: 13 July 2020

updates

\begin{abstract}
Our objective in this review article is to find out relevant information about methods of determination of antioxidant activity of silver nanoparticles. There are many studies dealing with mentioned problem and herein we summarize the knowledge about methods evaluating the antioxidant activity of silver nanoparticles reported so far. Many authors declare better antioxidant activity of silver nanoparticles compared to the extract used for synthesis of them. In this review, we focused on methods of antioxidant activity determination in detail to find out novel and perspective techniques to solve the general problems associated with the determination of antioxidant activity of silver nanoparticles.
\end{abstract}

Keywords: silver nanoparticles; antioxidant activity; silver nanoparticles synthesis

\section{Introduction}

Nanoscience and nanotechnology have been introduced as interdisciplinary fields in biology, chemistry, physics, and bioengineering. Nanoparticles, in general, are particles of size 1-100 nm and are considered extremely small as the term "nano" means dwarf (from Greek vávvo $\varsigma$ ) in the meaning of extremely small [1,2]. Unique chemical, physical, and biological properties lead to broad range of applications in electronics, sensors, spectral analysis, catalysis, or pharmaceutical industry in finding new ways of drug synthesis [3].

Antimicrobial properties are typical for silver and its compounds including silver nanoparticles (AgNPs) [4]. In view of the mentioned fact, the AgNPs are studied as antibacterial agents to inhibit resistant strains by multiple mechanisms of action, involving induction of oxidative stress, inhibition of DNA replication, or interaction with enzymes and proteins $[5,6]$. On the other hand, silver nanoparticles have a potential in the treatment of cancer $[7,8]$ or degenerative Alzheimer's disease because of their antioxidant properties [9]. For example, well characterized PVP-coated AgNPs were used in A549 cells (human lung cancer cells) to study reactive oxygen species production leading to programmed cell death [10]. Another study published by Lee et al. [11] was focused on cytotoxic activity in normal and cancer cell lines. They also showed significant cytotoxicity against A549 cells caused by green synthesized AgNPs from water extract of Annemarrhena asphodeloides. These nanoparticles also involved an increase in oxidative stress in A549 cells and inhibition of cell migration, but it is important to say that AgNPs do not exhibit significant toxicity to normal cell lines (3T3-L1 pre adipocyte cell lines) [11].

Antioxidant properties are currently extensively studied for various materials, including the natural ones, in order to identify new compounds from natural sources. The aim of this review is to 
provide a brief overview on antioxidant activity of silver nanoparticles, its measurement, and future perspectives in relationship between AgNPs and antioxidant activity.

\section{Antioxidant Activity}

\subsection{Oxidative Stress}

Oxidative stress is a phenomenon that can be defined as a state when the equilibrium between the antioxidative defense of cell and oxidants is disrupted by the effect of excess of the oxidants, for example reactive oxygen or nitrogen species (ROS or RNS, respectively) and organic compounds containing sulphur producing alkyl sulfanyl radicals (RS•). For example, transition metal ions at their lower oxidation states are not oxidant species by themselves, but may provoke the formation of ROS or RNS by reacting with hydrogen peroxide or molecular oxygen, thereby serve as prooxidants. Of course, also the presence of the oxidants leads to oxidative modifications of biological system on molecular level (unsaturated bonds of lipids, proteins, DNA, etc.,) causing damage and finally, cellular death is accelerated [12]. This phenomenon occurs when oxidative substances are excessively formed or accumulated and defense mechanisms have failed. Reactive oxygen species represent the most important group of oxidants containing radicals (hydroxyl $\bullet \mathrm{OH}$, superoxide ion $\mathrm{O}_{2}^{\bullet-}$ ), as well as non-radicals (hydrogen peroxide, organic peroxides) [13]. Superoxide and hydroxyl radical are products of oxygen reduction by electrons (Figure 1) [14,15].

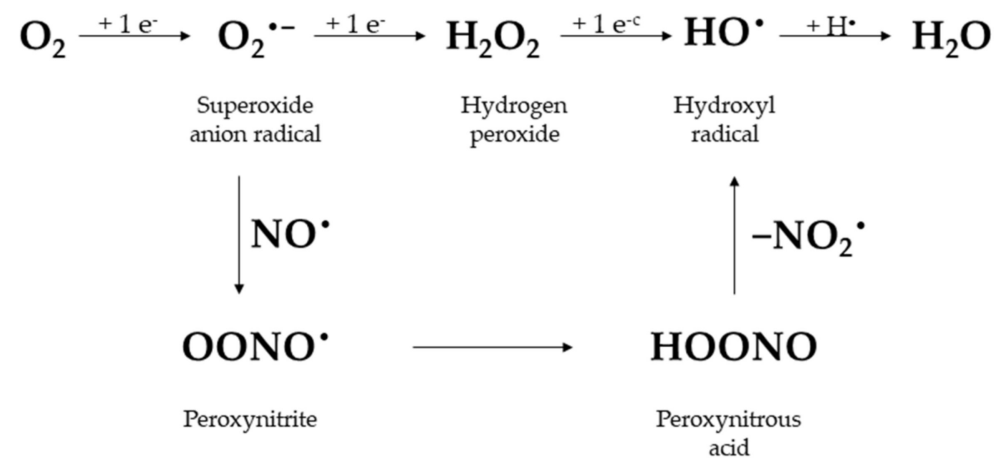

Figure 1. Some reactive oxygen and nitrogen compounds and relationships between them, redrawn from Greguška [15].

From biological point of view, superoxide anion radical $\mathrm{O}_{2}^{\bullet-}$ is generated by the mitochondrial respiratory chain and phagocytic NADPH oxidase (nicotinamide adenine dinucleotide phosphate oxidase; $\mathrm{NO}_{\mathrm{X}}$ ), so it is produced by respiration and component part of defense system [16]. It is known that human body produces around $5 \mathrm{~g}$ of ROS per day. These are with dynamic balance with the production of any oxygen forms essential for living and protection against the toxic influence of ROS [17]. In addition, an excessive amount of reactive nitrogen species is formed during the oxidative stress. The most common representative of RNS is nitroxide (NO•) produced by nitrogen oxidation catalyzed by NO-synthase [18]. NO• is able to rapidly react with reactive oxygen species (mainly with superoxide anion radical) and produce further reactive nitrogen compounds, for example peroxynitrite or peroxynitrous acid which can be further transformed to $\mathrm{NO}_{2} \bullet$ or $\bullet \mathrm{OH}$ (Figure 1). These products may initiate new radical reactions leading to damage of biomolecules (nitrosylation of DNA or proteins) [19].

The action of ROS and RNS leads to an oxidation of double bond of polyunsaturated fatty acids in lipids (lipoproteins, membrane structures) and formation of aldehydes or peroxides and a result of these processes is changing the membrane permeability $[20,21]$. The effect of oxidative stress on proteins leads to changes of ion transport (mainly $\mathrm{Ca}^{2+}$ ions homeostasis), protein inactivation, and enzymatic activity modification [22]. DNA is damaged by deoxyribose ring cleavage, base modification or chain 
breaks leading to mutations, translation errors or inhibition of proteosynthesis [23]. According to the mentioned facts, there is a connection between oxidative stress and several diseases caused by oxidative stress [24], e.g., Alzheimer's disease [25], atherosclerosis [18], cardiovascular diseases [20], cancer [26-28], but also psychic impairments, such as ADHD or schizophrenia [29,30].

Oxidative stress is induced by many generally known factors, including chemical, physical, or biological ones, and silver nanoparticles are no exception. Several studies described the cytotoxic effect of AgNPs through ROS generation [31-33]. On the other hand, the production of ROS, can be decreased by pre-treatment of cells by NAC ( $N$-acetylcysteine) as a systematic antioxidant [33].

It is necessary to note that oxidative stress has not only negative effects on human body, as free radicals have an irreplaceable function in living organisms. Definitely, one of the most important biological mechanism in which free radicals play an important role is the process of phagocytosis including the defense against pathogenic microorganisms [34].

Regarding the cell damage at molecular level caused by oxidative stress, the cell produces some intracellular or extracellular compounds serving as antioxidant defense systems.

\subsection{Antioxidants}

Antioxidants represent a form of opposition to oxidants. Antioxidants are natural or synthetic substances that may prevent or delay damage of cell caused by oxidants (ROS, RNS, free radicals, other unstable molecules) [12]. Halliwell and Gutteridge defined antioxidant as any substance that delays, prevents, or removes oxidative damage to a target molecule [35]. In order for the substance to be considered as an antioxidant, it must be active at low concentration (phenolic antioxidants often loose activity at high concentration and act as prooxidant), its amount needs to be satisfactory high to deactivate the target molecule, it must react with oxygen or nitrogen free radicals, and the final product of the reaction should be less toxic than removed radical. There is no universal antioxidant, as different antioxidants react with different reactive species by various mechanisms, at various locations and protect specific molecular targets $[35,36]$. Generally, the antioxidant defense can become active either by in vivo processes (synthesis of intracellular enzymes-superoxide dismutases, superoxide reductases, peroxiredoxins, glutathione peroxidases, catalases, peptides-glutathione; or in the form of extracellular antioxidant defenses-synthesis of transferrin, erythrocytes, albumin, urate, glucose; low-molecular mass agents_-bilirubin, $\alpha$-keto acids, melatonin, lipoic acid, coenzyme $\mathrm{Q}$, uric acid) or by supplying missing substances in the form of a diet (vitamins-C, E, A, D, riboflavin, thiamine, niacin, pyridoxine, carotenoids, flavonoids, polyphenols, amino acids, folic acid, phytoalexins, elements Se, $\mathrm{Fe}, \mathrm{Zn}, \mathrm{Mg})[35,37,38]$.

\section{Antioxidant Activity Determination Methods}

Determination of antioxidant activity (or capacity) of samples of various origin is based on different methodologies and assays. The principle of antioxidant capacity lies in chemistry, from which it was adapted to other scientific areas such as biology, medicine, nutrition $[39,40]$. In simple words, the antioxidant capacity describes the ability of molecules to scavenge free radicals [41]. In Table 1, we provide an overview of methods for antioxidant capacity evaluation and some of them are briefly described $[12,42-44]$.

\subsection{Spectrometric Methods}

In recent years, a broad range of spectrophotometric assays has been developed to measure antioxidant capacity. These methods are based on the reaction of colored radical or complex with the antioxidant molecule capable of donating a hydrogen atom. The appropriate standard (Trolox or ascorbic acid) is applied for quantification of antioxidant capacity as trolox equivalent antioxidant capacity (TEAC) or ascorbic acid equivalent antioxidant capacity (AEAC). In this part of our review we would like to pay attention to some methods which apply either AEAC or TEAC. 
Table 1. Methods for antioxidant capacity evaluation.

\begin{tabular}{|c|c|c|}
\hline Method & Principle & Final Product Determination \\
\hline \multicolumn{3}{|l|}{ Spectrometric } \\
\hline DPPH & Reaction with organic radical & Colorimetry \\
\hline ABTS & Reaction with organic radical & Colorimetry \\
\hline DMPD & Reaction with organic radical & Colorimetry \\
\hline FC & Reaction with $\mathrm{Mo}^{6+}$ and $\mathrm{W}^{6+}$ & Colorimetry \\
\hline FRAP & Reaction with $\mathrm{Fe}^{3+}$ & Colorimetry \\
\hline ORAC & $\begin{array}{c}\text { Reaction with peroxyl radical initiated by } \\
\text { AAPH }\end{array}$ & Fluorescence loss \\
\hline HORAC & $\begin{array}{l}\text { Reaction with } \mathrm{OH} \text { radicals generated by } \\
\mathrm{Co}^{2+} \text { based Fenton-like systems }\end{array}$ & Fluorescence loss \\
\hline TRAP & $\begin{array}{l}\text { Reaction with luminol-derived radicals, } \\
\text { generated during the AAPH decomposition }\end{array}$ & Quench of chemiluminescence \\
\hline Lipid peroxidation inhibitory assay & Fenton-like system $\left(\mathrm{Co}^{2+}+\mathrm{H}_{2} \mathrm{O}_{2}\right)$ & Colorimetry \\
\hline PFRAP & Potassium ferricyanide reduction & Colorimetry \\
\hline CUPRAC & $\mathrm{Cu}^{2+}$ reduction to $\mathrm{Cu}^{1+}$ & Colorimetry \\
\hline Fluorimetry & $\begin{array}{l}\text { Emission of light by a substance that has } \\
\text { absorbed the light or other electromagnetic } \\
\text { radiation of a different wavelength }\end{array}$ & $\begin{array}{c}\text { Fluorescence } \\
\text { excitation/emission spectra }\end{array}$ \\
\hline \multicolumn{3}{|l|}{ Electrochemical } \\
\hline Cyclic voltammetry & $\begin{array}{l}\text { The potential of working electrode is } \\
\text { varying from initial to final value and back, } \\
\text { current intensity is recorded }\end{array}$ & $\begin{array}{l}\text { Measurement of the intensity of } \\
\text { cathode or anode peak }\end{array}$ \\
\hline Amperometry & $\begin{array}{l}\text { The potential of working electrode is fixed } \\
\text { to a reference electrode }\end{array}$ & $\begin{array}{l}\text { Measurement of the intensity } \\
\text { currently produced by oxidation or } \\
\text { reduction of a sample }\end{array}$ \\
\hline Biamperometry & $\begin{array}{l}\text { The reaction of an antioxidant with the } \\
\text { oxidized form of a reversible redox couple }\end{array}$ & $\begin{array}{l}\text { Measurement of the current flow } \\
\text { between two identical } \\
\text { working electrodes }\end{array}$ \\
\hline \multicolumn{3}{|l|}{ Chromatographic } \\
\hline $\begin{array}{l}\text { High performance liquid } \\
\text { chromatography }\end{array}$ & $\begin{array}{l}\text { Separation of compounds in a reaction } \\
\text { mixture at a stationary phase in a liquid } \\
\text { mobile phase }\end{array}$ & UV/Vis, MS or fluorescence detection \\
\hline Biosensors & $\begin{array}{l}\text { Enzyme-based biosensors measuring total } \\
\text { phenolic content }\end{array}$ & Electroanalytical evaluation \\
\hline Nanotechnological methods & $\begin{array}{l}\text { Reaction of noble metal }(\mathrm{Au}, \mathrm{Ag}) \text { salt with } \\
\text { antioxidant compound }\end{array}$ & Colorimetry \\
\hline
\end{tabular}

Among the most frequently used methods for determining antioxidant capacity are the ABTS and DPPH assays. DPPH• (2,2-diphenyl-1-picrylhydrazyl) is a purple stable free radical reacting with hydrogen donor (Scheme 1). The presence of delocalized spare electrons on the whole molecule prevents dimerization and also gives the color to the molecule of DPPH with absorption maximum at around the value of $520 \mathrm{~nm}$ in UV/Vis spectra. The DPPH• radical after reaction gives the reduced form DPPH (hydrazine form), which results in the color change from purple to pale yellow. The level of disappearance of purple color depends on the concentration of the antioxidant. The scavenging capacity is usually determined in organic solvents, not in aqueous media [12,39,41,42,45,46].

It is a rapid, simple, and an inexpensive method for antioxidant capacity determination, but it has some limitations. The first is that DPPH radical can interact with other radicals and the time response curve is not linear with different ratio of antioxidant and DPPH [47]. Some problems may be observed in quantitative analysis because of interference of absorbance with compounds present in sample [48]. Finally, the DPPH method (as all the spectrometric methods) is unsuitable for emulsions since it reflects the partitioning of antioxidants and is also unsuitable for samples containing proteins which precipitate in alcohol [46]. 


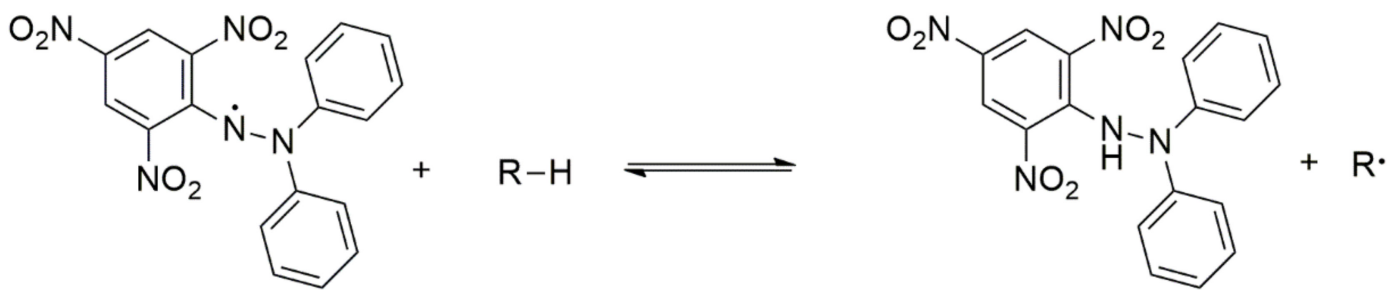

Scheme 1. Reaction of DPPH radical with hydrogen donor [46].

The ABTS (2,2'-azino-bis-3-ethylbenzthiazoline-6-sulphonic acid) method or the TEAC (trolox equivalent antioxidant capacity) is based on generating a cation radical ABTS $\bullet^{+}$formed by emitting one electron from the nitrogen atom (Scheme 2). ABTS is usually first oxidized by potassium persulphate [49], manganese dioxide [50], or AAPH (2,2'-azobis-(2-amidino-propane) dihydrochloride) [51] which gives rise to the cation radical $\mathrm{ABTS}^{\bullet+}$. It absorbs at $414,645,734$, and $815 \mathrm{~nm}$ and gives blue-green color. The preferred wavelength is $734 \mathrm{~nm}$ because the interference with other absorbing components is minimized. The $\mathrm{ABTS}^{\bullet+}$ reacts with antioxidant leading to the decolorization of a solution in the range of $1-30 \mathrm{~min}[12,39,41,42]$.<smiles>CCn1c(=N/N=c2\sc3cc(S(=O)(=O)O)ccc3n2CC)sc2cc(S(=O)(=O)O)ccc21</smiles>

ABTS<smiles></smiles>
$\downarrow \mathrm{AOH}$<smiles>CCn1c(=NNc2sc3cc(S(=O)(=O)O)ccc3[n+]2CC)sc2cc(S(=O)(=O)O)ccc21</smiles>

Scheme 2. Generating of $\mathrm{ABTS}^{\bullet+}$ and its reaction with an antioxidant [52].

The use of $\mathrm{ABTS}^{\bullet+}$ radical has the advantage over the DPPH radical as it can be used in both aqueous and organic media [48]. ABTS method is also useful in studying the effect of $\mathrm{pH}$ on the antioxidant activity of various compounds [53]. However, the ABTS assay has some reservations in the overall applications, such as specificity for reaction of different antioxidants, storage of the radical, or processing method conditions [53].

DMPD radical scavenging assay is based on the conversion of transparent $N, N$-dimethyl- $p$-phenylenediamine dihydrochloride (DMPD) into the colored radical DMPD ${ }^{\bullet+}$ in the presence of Fe ions or reactive species, such as hydroxyl radicals (Scheme 3). Antioxidants capable of hydrogen atom transfer decolorize the solution, absorbance decrease at $505 \mathrm{~nm}$ [12]. The main disadvantage of using this assay is that DMPD radical is soluble only in water, so there are limitations in using it for hydrophobic antioxidants determination [54]. 


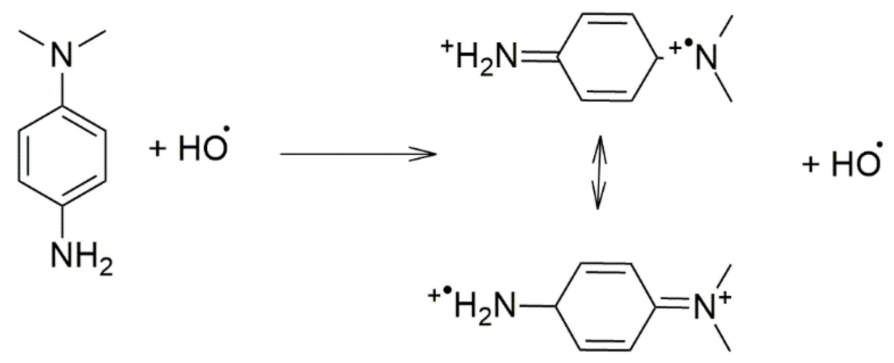

Scheme 3. Reaction of $N, N$-dimethyl-p-phenylenediamine with hydroxyl radical [55].

The FC (Folin-Ciocalteau) assay was initially developed for proteins analysis [56], but later this method was extended by Singleton [57] for the analysis of total phenolic compounds in wine. From chemical point of view, this method is based on the oxidation of phenolic compounds. Folin-Ciocalteau phenol reagent consists of a mixture of phosphomolybdic acid and phosphotungstic acid, in which the molybdenum and tungsten are in the oxidation state $6^{+}$and are reduced to the oxidation state of $5^{+}$during the reaction. This is accompanied by a color change from yellow original color of the solution of $\mathrm{Na}_{2} \mathrm{WO}_{4} / \mathrm{Na}_{2} \mathrm{MO}_{4}$ to blue because of the formation of complexes with phenols (Phenol- $\mathrm{MoW}_{11} \mathrm{O}_{40}{ }^{4-}$ ). The absorbance is usually measured in the range from 750-765 nm [43,44]. This method is mostly used for the determination of total phenolic compounds in various samples (food products, plants, plant extracts), but it can also react in alkaline conditions with non-phenolic compounds, such as amino acids, aromatic amines, ascorbic acid, sulphur dioxide, $\mathrm{Cu}^{+}$ions, and others [43].

The FRAP (ferric reducing antioxidant power) assay is based on reduction of colorless $\mathrm{Fe}^{3+}-2,4,6$-tripyridyl-s-triazine complex to the intensively blue $\mathrm{Fe}^{2+}-2,4,6$-tripyridyl-s-triazine complex in acidic medium (Scheme 4). FRAP values are calculated from increasing absorbances measured at $593 \mathrm{~nm}[39,42,43]$. The FRAP methods has several limitations. Compounds (even without antioxidant properties) with redox potential lower than the redox potential of $\mathrm{Fe}^{3+} / \mathrm{Fe}^{2+}$ pair may reduce $\mathrm{Fe}^{3+}$ to $\mathrm{Fe}^{2+}$ and can increase the FRAP value to obtain false high results. But, on the other hand, not all antioxidants reduce $\mathrm{Fe}^{3+}$ fast enough to measure [58]. Ferric reducing antioxidant power assay cannot be used for antioxidant acting as radical quench (with transfer of hydrogen) and for compounds absorbing at the wavelength of the determination, as the signals can interfere then $[43,58,59]$.

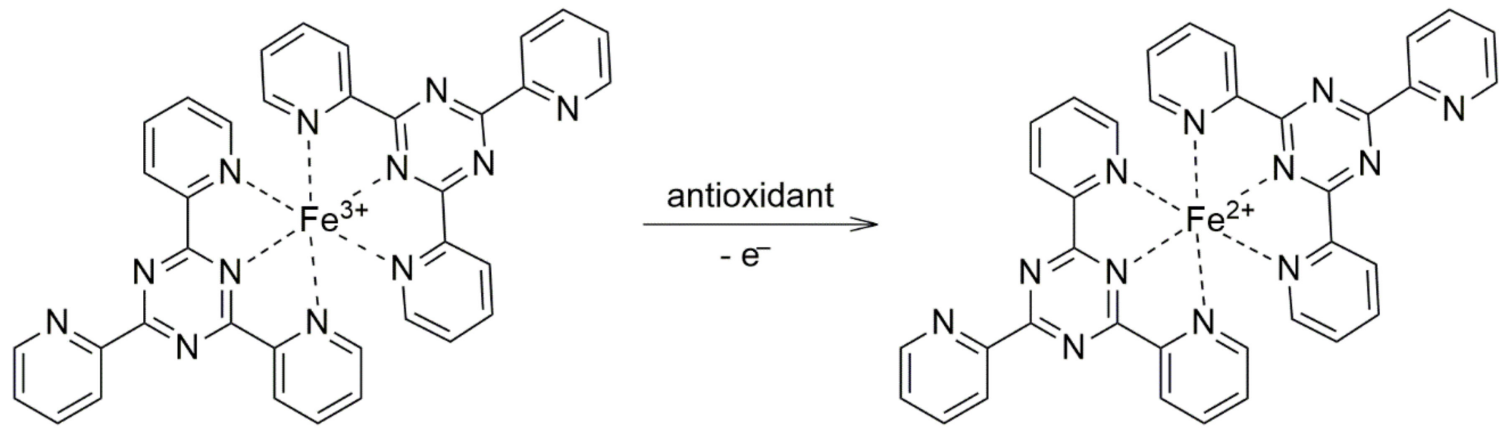

Scheme 4. Reduction of $\mathrm{Fe}^{3+}$ (FRAP assay) [52].

Oxygen radical absorbance capacity assay (ORAC) is the method for measuring the scavenging activity against peroxyl radicals. The generation of peroxyl radicals have to be induced by AAPH (2,2'-azobis-(2-amidino-propane) dihydrochloride). The antioxidant activity is measured by determining the loss of fluorescence and fluorescein is usually used as a probe [59,60]. This method is popular mainly in the determination of antioxidant ability of foods and is limited by low reactivity of fluorescein and with peroxyl radicals [61]. 
HORAC (hydroxyl radical averting capacity) technique is based on the oxidation of fluorescein by hydroxyl radicals which are generated using Fenton reagent. Formed antioxidant blocks produced hydroxyl radicals $[42,60]$.

Other method using the Fenton-like system to induce lipid peroxidation is lipid peroxidation inhibitory assay by measuring the thiobarbituric acid reactive substances (TBARS) $[12,42,60]$. This assay is based on the reaction of 2-thiobarbituric acid (TBA) with malondialdehyde (MDA) as one of the products of unsaturated lipids oxidation (Scheme 5) [61]. This method is limited by the possibility of MDA reaction with amino group to form Schiff base [62].<smiles>CC(C)(C)C(=O)CC=O</smiles>

Scheme 5. Reaction of two molecules of 2-thiobarbituric acid with malondialdehyde [61].

Other radical probes, such as TRAP (total peroxyl radical trapping antioxidant parameter) monitoring the reaction between peroxyl radicals and the sample quenched the chemiluminescence, CUPRAC (cupric reducing antioxidant power) by which the reduction of $\mathrm{Cu}^{2+}$ is observed, Fremy's salt (galvinoxyl radical), aroxyl radical (2,6-di-tert-butyl-4(4'-methoxyphenyl)phenoxyl radical) [42,60,63,64].

\subsection{Electrochemical Methods}

Electrochemical properties of various compounds can also be used for evaluation of their reducing and antioxidant properties. Electrochemical methods for the determination of total antioxidant capacity are widely used because of their sensitivity, speed, and low cost [65]. Essential electrochemical methods encompass cyclic voltammetry, amperometry, and biamperometry. Cyclic voltammetry $(\mathrm{CV})$ is a method based on the measurement of oxidation potential $\left(\mathrm{E}_{1 / 2}\right)$ intensity of the sample [43]. The oxidation potential is usually scanned linearly in time from an initial to a final value and back as a triangular waveform. Low values of oxidation potential reflect the tendency of molecule to donate an electron and indicate significant antioxidant capacity $[42,43,45,65]$. There are some limitations of this method because of the detection limit of $10^{-5} \mathrm{M}$ and low resolution [65]. The amperometric technique involves the measurement of the flowing current intensity between a working and a reference electrode at a fixed value of potential generated by the oxidation-reduction reaction [42,65]. This method is based on the reduction of DPPH $\bullet$ radical at a glassy carbon electrode [65-67]. Biamperometry uses two identical polarized platinum electrodes with high sensitivity $[42,65,68]$. The potential difference $(\Delta E)$ between the electrodes is controlled and the measurement depends on the reaction of the analyzed sample with redox couple [42,65].

\subsection{Chromatographic Methods}

Chromatography encompasses a group of broadly applicable methods in detection and separation of various compounds present in the analyte, but can also be used for antioxidant capacity measurement. The mostly preferred chromatographic methods are gas chromatography and high-performance liquid chromatography.

High-performance liquid chromatography (HPLC) is used to separate, identify, and quantify the individual components present in the analyte. This method is based on the affinity of analyte to a stationary phase, which is usually non-polar (reverse phase), but also polar (normal-phase) and is placed inside the column. The chosen composition of the mobile phase (eluent) depends on the used stationary phase and interactions between analytes. The separation process depends on affinity of analyte toward the stationary and mobile phases. The analyte flows through column in a liquid mobile 
phase to a detector (UV/Vis, DAD, MS, etc.). HPLC is a valuable method for antioxidant capacity determination. The antioxidant properties determination using HPLC system was applied by using on-line post-column detection. First, the separation of sample is promoted and then is mixed with radical solution (ABTS, DPPH). The solution is then directed to a detector and the obtained negative peaks represent a reaction of sample with radical [69-71].

\subsection{Biosensors Method}

Biosensors represent analytical tools consisting of a biological recognition element (enzyme, receptor, microorganism, antibody), coupled with a chemical or physical transducer (mass, electrochemical, optical, or thermal) [72]. Potential applications of biosensors for antioxidant capacity determination include monitoring of free radicals, such as nitric oxide $(\mathrm{NO})$, superoxide radical $\left(\mathrm{O}_{2}^{-}\right)$, glutathione (GSH), uric acid, ascorbic acid, or phenolic compounds [72,73].

\subsection{Nanotechnological Methods}

Nanotechnological techniques are usually based on colorimetric total antioxidant capacity assay. The formation of nanoparticles from noble metals, such as gold and silver, by the reaction between metallic salt $\left(\mathrm{Au}^{3+}, \mathrm{Ag}^{1+}\right)$ and antioxidant leads to the possibility of determination of antioxidant properties of studied samples [12]. When AgNPs are synthesized, the phenomenon of surface-plasmon resonance (SPR) is evident [74,75]. Because of this, metallic nanoparticles (NPs) have interesting attributes such as intensive color which can be detected in visible region of spectra [76]. Reducing compounds are necessary for the formation of nanosuspension, so natural antioxidants are mostly used for nanoparticles preparation and this fact gives the opportunities to detect physicochemical properties including total antioxidant capacity [77]. NPs can be also used for scavenging activity against ROS/RNS determination [77].

\section{Silver Nanoparticles and Antioxidant Activity Properties}

\subsection{AgNPs Synthesis}

Synthesis of Ag nanoparticles that are known mainly for their great antimicrobial activity can be achieved through various methods [78]. In general, we can divide these methods into physical, chemical, and biological. Some of these methods are simple and provide good control of nanoparticle size by affecting the reaction process, but on the other hand, there are still problems with stabilization of the obtained products and to achieve unimodal distribution in nano-region [79]. In Table 2 we show the list of some AgNPs synthesis techniques and several of them are briefly described below.

Table 2. Selected techniques for AgNPs preparation.

\begin{tabular}{|c|c|c|c|}
\hline \multicolumn{4}{|c|}{ Silver Nanoparticles Synthesis } \\
\hline \multirow{2}{*}{ Physical Methods } & \multirow{2}{*}{ Chemical Methods } & \multicolumn{2}{|c|}{ Green Synthesis Methods } \\
\hline & & In Vitro Methods & In Vivo Methods \\
\hline $\begin{array}{c}\text { Arc discharge } \\
\text { Ball milling } \\
\text { Evaporation-condensation } \\
\text { Pulsed laser ablation } \\
\text { Spray pyrolysis } \\
\text { Vapor and gas phase }\end{array}$ & $\begin{array}{c}\text { Electrochemical } \\
\text { Microwave assisted } \\
\text { Photochemical } \\
\text { Reduction } \\
\text { Sonochemical }\end{array}$ & $\begin{array}{c}\text { Using algae } \\
\text { Using biomolecules } \\
\text { Using essential oils } \\
\text { Using microorganisms } \\
\text { Using mushroom extracts } \\
\text { Using plant extracts }\end{array}$ & $\begin{array}{c}\text { Using algae } \\
\text { Using microorganisms } \\
\text { Using plant } \\
\text { Using yeast }\end{array}$ \\
\hline
\end{tabular}

\subsubsection{Physical Methods}

Physical approaches for AgNPs synthesis include evaporation-condensation, which has some disadvantages, such as high energy consumption, long time for achieving thermal stability [80,81]. For these reasons, various physical techniques were developed. Pluym et al. used conventional spray pyrolysis [82], Lee and his colleagues synthesized nanoparticles thermal decomposition [83], or ball 
milling was successfully used by Baláž [84]. This methodology, also called mechanochemical synthesis has recently attracted a significant attention of the research world [85-91]. Physical methods are useful because of speed and not using toxic chemicals, but on the other hand disadvantages are also there which are previously mentioned [80].

\subsubsection{Chemical Methods}

Chemical methods represent an easy way to prepare AgNPs in solution. The most common technique for nanoparticles preparation is the reduction by reducing agents of organic or inorganic character, for example sodium ascorbate, hydrogen, $N, N$-dimethyl formamide, or sodium borohydride. The principle of AgNPs preparation is the reduction of $\mathrm{Ag}^{+}$ion to metallic form $\mathrm{Ag}^{0}$ which is followed by agglomeration into oligomeric clusters leading to the formation of metallic colloidal AgNPs [92]. To avoid the agglomeration of nanoparticles, it is necessary to use stabilizing agents, such as poly(vinyl alcohol), poly(vinyl pyrrolidine), or polyethylene glycol [93-95].

\subsubsection{Biological Methods}

Biological synthesis of nanoparticles in general has become very popular because of its simplicity, low cost, or environmental reasons. The reduction of metallic salt is performed by a natural material including plants, plant extracts, microorganisms, or small biomolecules (amino acids, vitamins or polysaccharides) [96-99]. According to the used methodology, biological methods can be divided into in vivo and in vitro. In vivo methods use the whole cell for AgNPs biosynthesis, so nanoparticles are synthesized intra- or extracellularly, while during the in vitro process, the reduction of $\mathrm{Ag}^{+}$ions takes places outside of a living organism (the most common are plant extracts containing the compounds with antioxidant and reducing properties_-polyphenols, flavonoids, terpenes, aldehydes, carbohydrates, etc.,) [100-102]. In addition to plant extract, the extracts of edible mushrooms [103-105], extract of microorganisms [106-109], tissue extract [110], algae extract [111] essential oils [112], and simple biomolecules, such as glucose [113], starch [114], dextrin [115], pectin [99], or cellulose [116] can be used.

The term in vivo describes the biological synthesis of AgNPs inside the living organism. The very first article was published by Gardea-Torresdey et al. [117], who reported the synthesis of AgNPs by living plant alfalfa (Medicago salvia). They observed that the alfalfa root is able to absorb silver from agar medium to produce AgNPs. Microorganisms are also capable of producing nanoparticles. Some microorganisms are resistant to metal, so they can survive and grow during the production of NPs, so there is no barrier to use bacteria for AgNPs synthesis [118-120]. Fungi also represent a valuable producer of silver nanoparticles because of their capability of metals bioaccumulation [121,122].

\subsection{AgNPs Antioxidant Properties}

Antioxidant capacities of various biological samples, pure chemicals, or isolated compounds are well known. Beside the application of AgNPs in diverse areas, the large number of articles dealing with antioxidant properties of silver nanoparticles have been published spreading in the recent decade. In the Table 3 we have summarized the methods used for silver nanoparticles antioxidant capacity determination together with the methods of preparation during recent years. As it can be seen, the number of publications reporting on biosynthesis (especially using plant extract), has prevailed over any other method of synthesizing AgNPs, which may be justified by simplicity, availability, low cost of this approach (Table 3). 
Table 3. Methods of antioxidant capacity determination of prepared silver nanoparticles.

\begin{tabular}{|c|c|c|c|c|}
\hline $\begin{array}{l}\text { Method of Antioxidant } \\
\text { Capacity Measurement }\end{array}$ & $\begin{array}{c}\text { Method of } \\
\text { AgNPs Synthesis }\end{array}$ & Reducing Agent & Precursor & Ref. \\
\hline DPPH & Biological & $\begin{array}{l}\text { Plant extracts of Cratoxylum } \\
\text { formosum, Phoebe lanceolata, } \\
\text { Scurrula parasitica, Ceratostigma } \\
\text { minus, Mucuna birdwoodiana, } \\
\text { Myrsine africana and Lindera } \\
\text { strychnifolia }\end{array}$ & $0.25 \mathrm{mM} \mathrm{AgNO}_{3}$ & [123] \\
\hline DPPH & Biological & $\begin{array}{c}\text { Walnut (Juglans regia) green } \\
\text { husk extract }\end{array}$ & $6 \mathrm{mM} \mathrm{AgNO}_{3}$ & [124] \\
\hline $\mathrm{DPPH}$ & Biological & Plant extract of Costus afer & $1 \mathrm{mM} \mathrm{AgNO}_{3}$ & [127] \\
\hline DPPH & Biological & $\begin{array}{l}\text { Plant extract of Indigofera } \\
\text { tinctoria }\end{array}$ & $1 \mathrm{mM} \mathrm{AgNO} 3$ & [128] \\
\hline DPPH & Biological & $\begin{array}{l}\text { Red cabbage (Brassica oleracea } \\
\text { var. capitate f. rubra) extract }\end{array}$ & $5 \mathrm{mM} \mathrm{AgNO}_{3}$ & [125] \\
\hline DPPH & Biological & $\begin{array}{l}\text { Plant extract of Clerodendrum } \\
\text { inerme }\end{array}$ & $1 \mathrm{mM} \mathrm{AgNO}_{3}$ & [130] \\
\hline DPPH & Biological & $\begin{array}{l}\text { Plant extract of Rhododendron } \\
\text { dauricum }\end{array}$ & $0.5-5 \mathrm{mM} \mathrm{AgNO} 3$ & [131] \\
\hline DPPH & Biological & $\begin{array}{c}\text { Plant extract of Ougeinia } \\
\text { oojeinensis }\end{array}$ & $1 \mathrm{mM} \mathrm{AgNO}_{3}$ & [132] \\
\hline $\begin{array}{l}\text { DPPH } \\
\text { FC method }\end{array}$ & Biological & Plant extract of Bergenia ciliata & $0.1 \% \mathrm{AgNO}_{3}$ & [133] \\
\hline $\begin{array}{l}\text { DPPH } \\
\text { FRAP }\end{array}$ & Biological & Plant extract of Prosopis farcta & $1 \mathrm{mM} \mathrm{AgNO} 3$ & [134] \\
\hline $\begin{array}{c}\text { DPPH } \\
\text { ABTS } \\
\bullet \text { OH } \\
\text { Superoxide anion } \\
\text { NO } \\
\end{array}$ & Biological & $\begin{array}{l}\text { Plant extract of Pongamia } \\
\text { pinnata }\end{array}$ & $1 \mathrm{mM} \mathrm{AgNO}_{3}$ & [135] \\
\hline $\begin{array}{l}\text { DPPH } \\
\text { ABTS }\end{array}$ & Biological & $\begin{array}{l}\text { Plant extract of Tropaeolum } \\
\text { majus }\end{array}$ & $1 \mathrm{mM} \mathrm{AgNO} 3$ & [136] \\
\hline $\begin{array}{l}\text { DPPH } \\
\text { ABTS }\end{array}$ & Biological & $\begin{array}{l}\text { Plant extract of Allium } \\
\text { ampeloprasum L. }\end{array}$ & $1 \mathrm{mM} \mathrm{AgNO}_{3}$ & [137] \\
\hline $\begin{array}{l}\text { DPPH } \\
\text { ABTS } \\
\mathrm{NO}_{x}\end{array}$ & Biological & $\begin{array}{l}\text { Peels' extract of Ipomoea batatas } \\
\text { (L.) }\end{array}$ & $1 \mathrm{mM} \mathrm{AgNO}_{3}$ & [138] \\
\hline $\begin{array}{l}\text { DPPH } \\
\text { ABTS }\end{array}$ & Biological & $\begin{array}{l}\text { Plant extracts of Allium sativum, } \\
\text { Zingiber officinale, Capsicum } \\
\text { frutescens }\end{array}$ & $0.1 \mathrm{M} \mathrm{AgNO}_{3}$ & [139] \\
\hline $\begin{array}{l}\text { DPPH } \\
\text { ABTS } \\
\mathrm{NO}_{x} \\
\end{array}$ & Biological & $\begin{array}{c}\text { Plant extract of Taraxacum } \\
\text { officinale }\end{array}$ & $1 \mathrm{mM} \mathrm{AgNO}_{3}$ & [140] \\
\hline $\begin{array}{l}\text { DPPH } \\
\text { FRAP }\end{array}$ & Biological & Plant extract of Teucrium polium & $3 \mathrm{mM} \mathrm{AgNO} 3$ & [141] \\
\hline DPPH & Biological & $\begin{array}{c}\text { Plant extract of Pulicaria } \\
\text { vulgaris }\end{array}$ & $1 \mathrm{mM} \mathrm{\textrm {AgNO } _ { 3 }}$ & [142] \\
\hline DPPH & Biological & $\begin{array}{l}\text { Plant extract of Gynura } \\
\text { procumbens encapsulated with } \\
\text { fungal chitosan from } \\
\text { Cunninghamella elegans }\end{array}$ & $1 \mathrm{mM} \mathrm{AgNO}_{3}$ & [143] \\
\hline $\begin{array}{c}\text { DPPH } \\
\text { Reducing power } \\
\text { Superoxide anion }\end{array}$ & Biological & $\begin{array}{c}\text { Plant extract of Aesculus } \\
\text { hippocastanum }\end{array}$ & $5 \mathrm{mM} \mathrm{AgNO}_{3}$ & [126] \\
\hline $\begin{array}{c}\text { DPPH } \\
\text { FC } \\
\text { Superoxide anion }\end{array}$ & Biological & $\begin{array}{l}\text { Plant extract of Indian } \\
\text { belladonna }\end{array}$ & $1 \mathrm{mM} \mathrm{AgNO}_{3}$ & [144] \\
\hline
\end{tabular}


Table 3. Cont.

\begin{tabular}{|c|c|c|c|c|}
\hline $\begin{array}{l}\text { Method of Antioxidant } \\
\text { Capacity Measurement }\end{array}$ & $\begin{array}{c}\text { Method of } \\
\text { AgNPs Synthesis }\end{array}$ & Reducing Agent & Precursor & Ref. \\
\hline $\begin{array}{l}\text { DPPH } \\
\text { ABTS }\end{array}$ & Biological & Plant extract of Melia azedarach & $1 \mathrm{mM} \mathrm{AgNO}_{3}$ & [129] \\
\hline $\begin{array}{c}\mathrm{DPPH} \\
\mathrm{ABTS} \\
\bullet \mathrm{OH} \\
\text { Superoxide anion } \\
\mathrm{H}_{2} \mathrm{O}_{2} \\
\end{array}$ & Biological & $\begin{array}{c}\text { Extract of garlic (Allium } \\
\text { sativum), green tea (Camellia } \\
\text { sinensis), turmeric (Curcuma } \\
\text { longa) }\end{array}$ & $25 \mathrm{mM} \mathrm{AgNO}_{3}$ & [145] \\
\hline $\begin{array}{l}\text { DPPH } \\
\text { ABTS }\end{array}$ & Biological & $\begin{array}{c}\text { Plant extract of Psidium guajava } \\
\text { L. }\end{array}$ & $1 \mathrm{mM} \mathrm{AgNO} 3$ & [146] \\
\hline $\begin{array}{l}\text { DPPH } \\
\text { FRAP }\end{array}$ & Biological & $\begin{array}{c}\text { Plant extract of Bauhinia } \\
\text { variegata }\end{array}$ & $1 \mathrm{mM} \mathrm{AgNO} 3$ & [147] \\
\hline $\mathrm{DPPH}$ & Biological & $\begin{array}{l}\text { Plant extract of Achillea } \\
\text { millefolium }\end{array}$ & $1 \mathrm{mM} \mathrm{AgNO} 3$ & {$[148]$} \\
\hline DPPH & Biological & $\begin{array}{l}\text { Plant extract of Datura } \\
\text { stramonium }\end{array}$ & $1 \mathrm{mM} \mathrm{AgNO} 3$ & [149] \\
\hline $\begin{array}{l}\text { DPPH } \\
\text { ABTS }\end{array}$ & Biological & Corn (Zea mays) flour extract & $1 \mathrm{mM} \mathrm{AgNO}_{3}$ & {$[150]$} \\
\hline $\begin{array}{c}\text { Superoxide } \\
\mathrm{H}_{2} \mathrm{O}_{2} \\
\mathrm{NO} \\
\mathrm{DPPH} \\
\bullet \mathrm{OH}\end{array}$ & Biological & Essential oil of Coleus aromaticus & $0.214 \mathrm{mM} \mathrm{AgNO}_{3}$ & {$[151]$} \\
\hline $\begin{array}{l}\text { DPPH } \\
\text { FC }\end{array}$ & Biological & Macroalgae Ulva lactuca L. & $5 \mathrm{mM} \mathrm{AgNO} 3$ & {$[152]$} \\
\hline DPPH & Biological & $\begin{array}{l}\text { Bacterial strain Trichoderma } \\
\text { atroviride }\end{array}$ & $\begin{array}{c}5 \text { and } 10 \mathrm{mM} \\
\mathrm{AgNO}_{3}\end{array}$ & [153] \\
\hline $\begin{array}{c}\mathrm{DPPH} \\
\mathrm{H}_{2} \mathrm{O}_{2} \\
\mathrm{NO}\end{array}$ & Biological & $\begin{array}{l}\text { Exopolysaccharide from } \\
\text { probiotic Lactobacillus brevis }\end{array}$ & $2 \mathrm{mM} \mathrm{AgNO}_{3}$ & {$[154]$} \\
\hline $\begin{array}{c}\mathrm{DPPH} \\
\mathrm{H}_{2} \mathrm{O}_{2} \\
\mathrm{NO} \\
\text { Ferric reducing power } \\
\text { assay } \\
\end{array}$ & Biological & $\begin{array}{l}\text { Exopolysaccharide from } \\
\text { Streptomyces violaceus }\end{array}$ & $3 \mathrm{mM} \mathrm{AgNO}_{3}$ & [155] \\
\hline $\mathrm{DPPH}$ & Biological & Ochrobactrum rhizosphaerae & $9 \mathrm{mM} \mathrm{AgNO}_{3}$ & [156] \\
\hline $\begin{array}{l}\text { DPPH } \\
\text { ABTS } \\
\text { MTT } \\
\text { FC }\end{array}$ & Biological & Syzygium cumini fruit extract & $0.5-5 \mathrm{mM} \mathrm{AgNO}_{3}$ & [157] \\
\hline DPPH & Chemical & Sodium citrate & $\begin{array}{c}45 \mathrm{mg} \mathrm{AgNO}_{3} \\
\text { Stabilized by PVP } \\
\text { or PVA }\end{array}$ & {$[158]$} \\
\hline $\begin{array}{l}\text { TAC } \\
\text { TBARS } \\
\text { PCARB } \\
\text { GSH } \\
\end{array}$ & Chemical & $\begin{array}{c}\text { EG } \\
\text { EG/PVP }\end{array}$ & $\mathrm{AgNO}_{3}$ & [159] \\
\hline $\begin{array}{l}\text { DPPH } \\
\text { ABTS } \\
\mathrm{H}_{2} \mathrm{O}_{2} \\
\end{array}$ & Chemical & PABA-PVA & $\begin{array}{c}0.1 \mathrm{M} \\
\mathrm{AgNO}_{3} \mathrm{NaOH}\end{array}$ & {$[160]$} \\
\hline $\mathrm{DPPH}$ & Chemical & PLA/PEG & $1 \mathrm{mM} \mathrm{AgNO}_{3}$ & [149] \\
\hline $\begin{array}{l}\text { DPPH } \\
\text { ABTS }\end{array}$ & Chemical & Phenolic compounds & $\begin{array}{c}\mathrm{AgNO}_{3} \\
\text { Stabilized by PVP } \\
\mathrm{NaOH} \\
\end{array}$ & {$[161]$} \\
\hline
\end{tabular}

EG—ethylene glycol; EG/PVP—ethylene glycol/poly(vinyl pyrollidine); PABA-PVA—poly(3-aminophenyl boronic acid- poly(vinyl alcohol); PLA/PEG-poly lactic acid/poly ethylene glycol.

From the Table 3 it is also clear that the most commonly used method of AgNPs antioxidant capacity determination is DPPH assay. Authors usually compare the antioxidant capacity of extract 
with that of prepared silver nanoparticles. In general, contradictory results can be found in literature. For example, Ahn et al. [123] determined antioxidant capacity of thirty plant extracts and AgNPs prepared by using them with the conclusion that the scavenging activity using DPPH assay increased with higher amounts of either extract or AgNPs. In general, the extracts showed better scavenging activity than the AgNPs (Figure 2a). Authors explained this phenomenon by the role of phytochemicals. An extract with high scavenging activity leads to the rapid formation of small AgNPs seeds, which grow into larger nanoparticles with assistance of phytochemicals presented in the matrix [123]. A reduced antioxidant capacity of AgNPs in comparison with extract was also observed by Demirbas [125]. They prepared silver nanoparticles by biological method using extract of red cabbage (Brassica oleracea var. capitate f. rubra). The authors proposed that AgNPs were synthesized using antioxidant power of red cabbage extract to reduce $\mathrm{Ag}^{+}$ions, so AgNPs may promote superoxide radicals which would consume antioxidant capacity of red cabbage [125]. Lower values of silver nanoparticles (prepared by Aesculus hippocastanum) antioxidant capacity was also obtained by Küp [126] who used three different method of scavenging activity determination-DPPH, total reducing power, and superoxide anion radical scavenging assay. The results of DPPH and superoxide anion radical scavenging assays lead to reduced antioxidant capacity of prepared nanoparticles in comparison to plant extract, but the total reducing power of AgNPs indicated more reducing activity than plant extract. The relevant explanation is missing, but authors rely on the fact that reducing power may serve as a major sign of potential antioxidant activity because of the ability of reduction of the $\mathrm{Fe}^{3+}$ ferricyanide complex [126].

On the other hand, nanoparticles prepared by Zarrabi et al. [124] showed higher scavenging activity of free radicals by DPPH method than walnut (Juglans regia) extract (Figure 2b). They speculated that improved antioxidant properties of AgNPs are due to the simultaneous activity of polyphenols as antioxidant agents and AgNPs as a catalyst [124]. Similar results were noticed by study Elemike et al. [127], who prepared Ag nanoparticles by Costus afer. AgNPs showed greater antioxidant capacity than the leaf extract and their activity was comparable to that of ascorbic acid [127]. The present phytochemicals (flavonoids) and silver ions could serve as antioxidants through single electron and hydrogen atom transfer [127]. Other theory was presented by Vijayan et al. [128], who indicate that the increased antioxidant properties of nanoparticles compared to extract can be attributed to the adsorption of bioactive compounds of leaf extract over spherically shaped nanoparticles. Analogically, AgNPs prepared by extract of Melia azedarach exhibited higher antioxidant capacity according to extract [129]. According to the authors, the antioxidant ability of AgNPs is caused by the presence of phenolic compounds, terpenoids, and flavonoids in plants which allow nanoparticles to act as singlet oxygen quenchers, hydrogen donors, and reducing agents [129].

An interesting study was published by Das and his co-workers, who studied the antioxidant properties of two types of biosynthesized AgNPs by sweet potatoes Ipomoea batatas (L.) [138]. They compared three assays-ABTS, DPPH, and $\mathrm{NO}_{\mathrm{x}}$ (nitrite/nitrate oxide) at variety of concentrations. The ABTS scavenging activity proceeded in the range of $3.98-12.28 \%$, for DPPH it was $26.30-46.53 \%$, and for $\mathrm{NO}_{\mathrm{x}}$ the values were $4.30-12.94 \%$. The moderate scavenging effect might arise from the interference of several functional groups presented in extract, which play an important role in the capping and stabilizing on AgNPs. The scavenging activity against DPPH radical is higher than that against ABTS and $\mathrm{NO}_{\mathrm{x}}$. Lower values of antioxidant capacity against $\mathrm{NO}_{x}$ were explained by the difference in the reaction mechanism [138]. Comparison of ABTS and DPPH assay was also published by Otunola [139]. In that study, AgNPs were prepared by garlic (Allium sativum), ginger (Zingiber officinale), and cayenne pepper (Capsicum frutescens) extracts. The AgNPs exhibited potential antioxidant properties against both radicals expressed as $\mathrm{IC}_{50}$ values. The highest activity against ABTS was evidenced for cayenne pepper ( $\mathrm{IC}_{50}$ was $31.25 \mu \mathrm{g} / \mathrm{mL}$ ), whereas the highest value of $\mathrm{IC}_{50}(<31.25 \mu \mathrm{g} / \mathrm{mL})$ against DPPH radicals was observed for garlic [139]. 
(a)

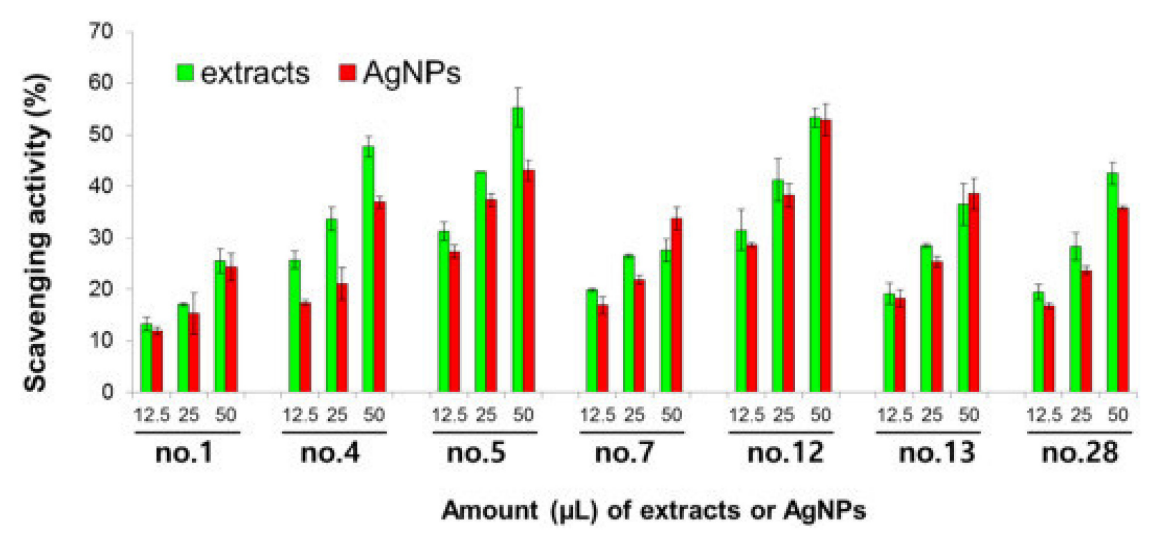

(b)

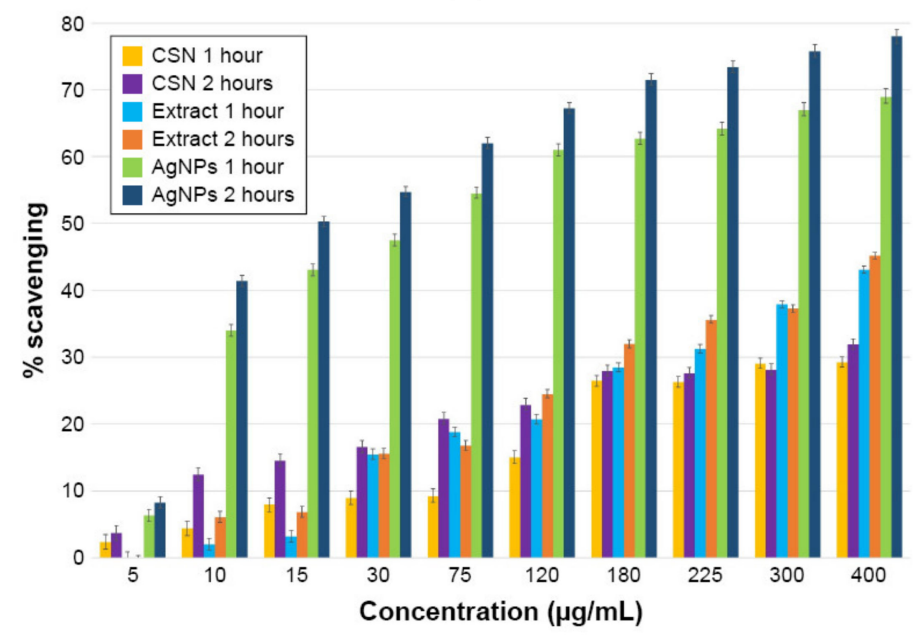

Figure 2. DPPH scavenging activity of (a) AgNPs prepared by Chinese plants extract [123], copyright permission by Elsevier; (b) AgNPs prepared by walnut green husk extract increasing in concentration and time [124], copyright permission by Dovepress.

The DPPH and ABTS assays were also compared by measurements of antioxidant capacity of AgNPs prepared by extract of Allium ampeloprasum L. [137]. The antioxidant capacity was determined at different concentrations (100, 200, 300, 400 and $500 \mathrm{mM}$ ). The DPPH and ABTS radical scavenging abilities were dose-dependent, which means that increasing scavenging activities against both radicals with the increasing concentration of AgNPs were observed (for DPPH and ABTS the antioxidant activity was in the range $62.2-82.4 \%$ and $64.5-96.8 \%$, respectively). These results can be considered slightly inadequate, because the authors did not compare the antioxidant capacity with that of standard, so it can be only hypothesized that silver nanoparticles prepared by using the extract of Allium ampeloprasum L. exhibit good antioxidant activity [137].

In addition to plant extract, bacterial strains are also used for AgNPs biosynthesis. As an example, the study on the use of Trichoderma atroviride for this purpose can be mentioned [153]. The presented work showed that AgNPs exhibited quite higher DPPH scavenging activity in a concentration-dependent manner with $\mathrm{IC}_{50}$ of $45.6 \mu \mathrm{g} / \mathrm{mL}$ [153].

Biomolecules isolated from microorganisms, such as exopolysaccharides were also used for biosynthesis of AgNPs [154,155]. Promising antioxidant properties were reported by Sivasankar et al. [155], who studied antioxidant capacity of silver nanoparticles prepared by exopolysaccharides isolated from Streptomyces violaceus. They focused on $\mathrm{DPPH}, \mathrm{NO}$, and $\mathrm{H}_{2} \mathrm{O}_{2}$ scavenging activities, total antioxidant activity, and ferric reducing power assay using ferricyanide (Figure 3). The AgNPs showed the DPPH radical scavenging effect of $89.5 \%$ at 
concentration of $50 \mu \mathrm{g} / \mathrm{mL}$, which was higher than in the case of ascorbic acid standard (49.6\%). Analogically, they found higher total antioxidant activity of AgNPs compared to the standard. Hydrogen peroxide scavenging activity of the studied AgNPs (72.5\%) was also higher than standard (56.4\%). The authors explained the results based on the hypothesis that in the presence of $\mathrm{H}_{2} \mathrm{O}_{2}$ the dispersed nanoparticles may induce the formation of reactive oxygen species and hydrogen peroxide inside a cell. Then AgNPs yield greater amounts of hydrogen peroxide and induce inflammasome formation leading to the production of superoxide and $\mathrm{H}_{2} \mathrm{O}_{2}$ in the mitochondria's membrane [155]. Nitric oxide assay also showed a significant activity of AgNPs (60.1\%) being higher than that of L-ascorbic acid (41.2\%). Ferric reducing power of AgNPs was lower than that of ascorbic acid standard and was higher at lower concentrations of AgNPs. These findings make the silver nanoparticles useful for neurodegenerative diseases, cancer, or AIDS treatment [155,162].
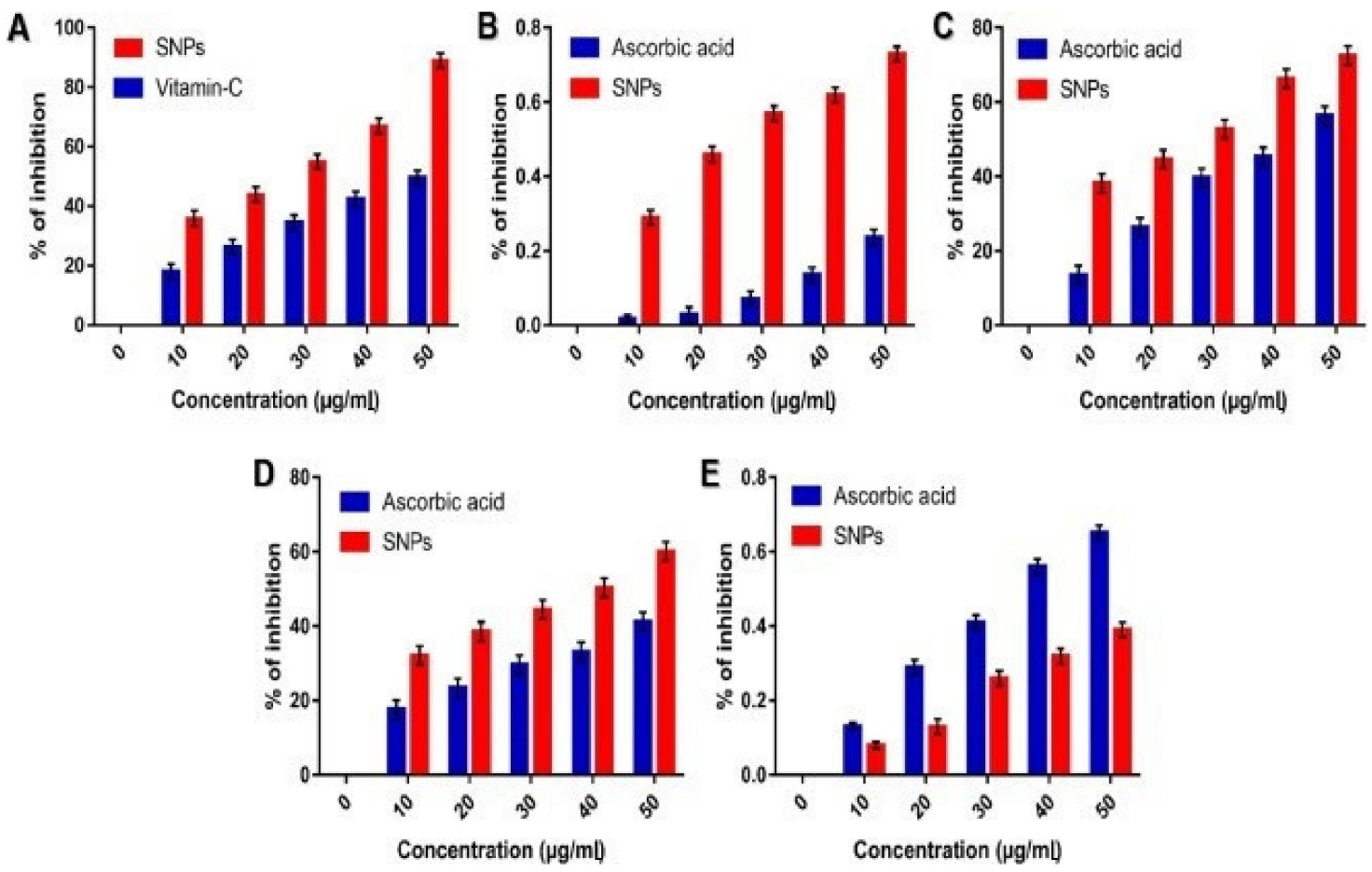

Figure 3. (A) DPPH assay, (B) total antioxidant activity, (C) $\mathrm{H}_{2} \mathrm{O}_{2}$ scavenging activity, (D) nitric oxide scavenging activity, (E) ferric reducing power assay of $S$. violaceus MM72 exopolysaccharide-mediated AgNPs with their respective standards. The data represent mean \pm SD of the three replicates $(n=3)$ [155], copyright permission by Elsevier.

Similar results were published by Shahid et al. [154] who determined antioxidant properties of silver nanoparticles prepared by exopolysaccharides from Lactobacillus brevis. The focus was on nitric oxide, DPPH, and hydrogen peroxide radical scavenging activity. The authors observed excellent nitric oxide scavenging activity of AgNPs in a concentration-dependent manner, but the activity was in general lower than that of ascorbic acid standard. At concentration of $100 \mu \mathrm{g} \cdot \mathrm{mL}^{-1}$ they determined the activity to be $75.06 \pm 0.4 \%$, whereas for ascorbic acid, it was $91.1 \pm 1.5 \%$. Hydrogen peroxide and DPPH scavenging activity of AgNPs was also compared with ascorbic acid. On the contrary to $\mathrm{NO}_{\mathrm{x}}$ assay, the ability to scavenge both free radicals of silver nanoparticles was higher than that of the standard used. Namely, for AgNPs with concentration of $100 \mu \mathrm{g} \cdot \mathrm{mL}^{-1}$ the activity of $\mathrm{H}_{2} \mathrm{O}_{2}$ scavenging was $70.1 \pm 0.6 \%$ and in the case of DPPH assay it was $91.3 \pm 0.7 \%$. The ascorbic acid standard showed $55.0 \pm 0.7 \%$ activity for hydrogen peroxide technique and $81.4 \pm 1.2 \%$ for DPPH radical scavenging activity [154].

The free radical scavenging activity of Teucrium polium extract, and of AgNPs produced chemically and by green synthesis was studied by DPPH and FRAP assays in [163]. The results show that the 
activity of green synthesized silver NPs increased with higher concentration, while that of chemically synthesized nanoparticles did not show a significant antioxidant activity. The antioxidant capacity of green-synthesized AgNPs was similar to that of plant extract. The authors explained these results by a suggestion that the presence of bioactive compounds on the surface of AgNPs is responsible for the majority of antioxidant capacity and silver nanoparticles are not contributing much [163].

DPPH method was used to determine free radical scavenging activity of silver nanoparticles prepared chemically (using sodium citrate served as reducing agent) and biologically (using extract of Datura stramonium plant as a reducing agent) in [149]. The DPPH radical scavenging ability of green and chemically prepared AgNPs was compared with that of plant extract. Better results were observed for green-synthesized silver nanoparticles [149].

Mittal [157] and his co-workers published a study dealing with the synthesis of AgNPs using Syzygium cumini extract. They observed that the reduction of silver ions and stabilization of prepared AgNPs were mainly because of the action of flavonoids. The authors evaluated the antioxidant properties by Folin-Ciocalteau's assay for total phenolic and flavonoid content, DPPH, ABTS, and MTT methods. The total phenolic content was lower $(8.1 \pm 0.1 \%)$ than the total flavonoid content $(81.2 \pm 0.27 \%)$, so they concluded that the amount of flavonoids present in silver nanoparticles was ten times higher which was in good agreement with the isolated flavonoids from extract. The DPPH assay showed antioxidant capacity of 59\% (in comparison to $87 \%$ detected by Trolox at the same concentration). On the other hand, upon using ABTS method, they observed $63 \%$ scavenging activity and when using MTT test, $61 \%$ scavenging activity at the same concentration $\left(50 \mu \mathrm{g} \cdot \mathrm{mL}^{-1}\right) \mathrm{was}$ observed [157].

Various phenolic compounds including flavonoids (quercetin, rutin, hesperidin), benzoic acids (gallic acid, protocatechuic acid sylicylic acid, benzoic acid), and cinnamic acids (caffeic acid, ferulic acid, $p$-coumaric acid and trans-cinnamic acid) were used for silver nanoparticles synthesis in [161]. The antioxidant capacities of structurally different phenolic compounds were evaluated. The hydroxylation of aromatic ring played an important role in the reactivity to form silver NPs. The higher degree of hydroxylation in chemical structures of phenolic compounds demonstrated the higher radical scavenging capacity and higher tendency to reduce $\mathrm{Ag}^{+}$to $\mathrm{AgNPs}^{\text {[161] }}$.

(PABA-PVA) AgNPs were subjected to the ABTS, DPPH, and $\mathrm{H}_{2} \mathrm{O}_{2}$ radical scavenging activities measurements in [160]. All tested nanoparticles have exhibited lower scavenging activity than ascorbic acid standard. The highest free radical scavenging activity was determined against DPPH radical followed by $\mathrm{H}_{2} \mathrm{O}_{2}$ and ABTS methods [160].

The expression of antioxidant activity only as a percentage of inhibition has little significance, as antioxidant activity is strongly dependent on conditions, such as solvent and concentration of radicals. In any case, it is better to express or compare the activity with a standard (ascorbic acid, trolox, gallic acid, quercetin, etc.). When comparing the activity with the extract, the choice of concentration seems to be a key factor influencing the result, as the antioxidant activity is concentration-dependent. The resulting antioxidant activity of the nanoparticles significantly depends mainly on the reducing substances in the extract bounded/capped to the surface of the nanoparticles.

For the basic study of antioxidant activity, the use of various in vitro methods is a suitable choice, either with a mechanism of action such as hydrogen transfer or electron transfer. In these methods, the mechanism of antioxidant action of silver nanoparticles can be ascribed to the fact that silver can exist in two oxidation states $\left(\mathrm{Ag}^{+}\right.$and $\left.\mathrm{Ag}^{2+}\right)$ depending on the reaction conditions and the produced AgNPs may be able to quench free radicals by donating or accepting electrons [164]. Nanoparticles have been shown to have a more complicated mechanism of action in biological systems using in vivo activity-based methods.

\section{Conclusions}

This brief review provided an overview on the antioxidant activity of silver nanoparticles and the methods of its measurement. Generally, there are three methods for AgNPs synthesis—biological, physical, 
and chemical. Obviously, the most commonly used synthesis approach to AgNPs synthesis is the biological one, which utilizes mainly plant extracts to reduce silver ion to form and stabilize the $\mathrm{Ag}^{0}$ nanoparticles. This approach is becoming more popular because of the environmental and economic reasons.

The antioxidant properties of AgNPs are usually evaluated by DPPH and ABTS free radical scavenging assays. As the most established nanoparticles are synthesized using plant extracts, the antioxidant capacity of AgNPs is often compared with plant extract itself. The results are contradictory, as some authors observed higher antioxidant capacity of AgNPs, whereas on the other hand, there are also studies with the opposite results. Based on the large number of papers reporting both types of results, it seems that both scenarios are possible. In general, the antioxidant properties of silver nanoparticles depend on the chemical composition of the extract and it usually improves with the increase of the AgNPs concentration. If the extract is rich in phenolic compounds and flavonoids, the nanoparticles exhibit high scavenging activity.

This review has shown that there are many methods used for antioxidant capacity determination. It is hard to conclude which method is the most suitable because of various composition of nanoparticles synthesized by biological methods depending on the phytochemicals presented in plant extracts. The antioxidant test models vary in different aspects. Therefore, the total antioxidant capacity cannot by evaluated on the basis of a single antioxidant test model and it is also difficult to compare one method with another. In the present state, the use of combination of different methods is always beneficial. However, understanding the roles of various antioxidants and their activities is challenging. Because of this, there is an enormous need to develop a uniform protocol for determining the antioxidant capacity of nanoparticles to precisely assess their potential.

Funding: This study was supported by Slovak Grant Agency VEGA (2/0044/18) and by Slovak Research and Development Agency (contract APVV-18-0357).

Conflicts of Interest: The authors declare no conflict of interest.

\section{References}

1. Rai, M.; Yadav, A.; Gade, A. Silver nanoparticles as a new generation of antimicrobials. Biotechnol. Adv. 2009, 27, 76-83. [CrossRef] [PubMed]

2. Pandit, R. Green synthesis of silver nanoparticles from seed extract of Brassica nigra and its antibacterial activity. Nusant. Biosci. 2015, 7, 15-19. [CrossRef]

3. Abbasi, E.; Milani, M.; Fekri Aval, S.; Kouhi, M.; Akbarzadeh, A.; Tayefi Nasrabadi, H.; Nikasa, P.; Joo, S.W.; Hanifehpour, Y.; Nejati-Koshki, K.; et al. Silver nanoparticles: Synthesis methods, bio-applications and properties. Crit. Rev. Microbiol. 2014, 42, 1-8. [CrossRef] [PubMed]

4. Jiang, H.; Manolache, S.; Wong, A.C.L.; Denes, F.S. Plasma-enhanced deposition of silver nanoparticles onto polymer and metal surfaces for the generation of antimicrobial characteristics. J. Appl. Polym. Sci. 2004, 93, 1411-1422. [CrossRef]

5. Hwang, I.; Hwang, J.H.; Choi, H.; Kim, K.-J.; Lee, D.G. Synergistic effects between silver nanoparticles and antibiotics and the mechanisms involved. J. Med. Microbiol. 2012, 61, 1719-1726. [CrossRef]

6. Tian, X.; Jiang, X.; Welch, C.; Croley, T.R.; Wong, T.; Chen, C.; Fan, S.; Chong, Y.; Li, R.; Ge, C.; et al. Bactericidal effects of silver nanoparticles on lactobacilli and the underlying mechanism bactericidal effects of silver nanoparticles on lactobacilli and the underlying mechanism. Appl. Mater. Interfaces 2018, 10, 8443-8450. [CrossRef]

7. Jacob, S.J.P.; Finub, J.S.; Narayanan, A. Biointerfaces synthesis of silver nanoparticles using piper longum leaf extracts and its cytotoxic activity against Hep-2 cell line. Colloids Surf. B Biointerfaces 2012, 91, $212-214$. [CrossRef]

8. Wei, L.; Lu, J.; Xu, H.; Patel, A.; Chen, Z.-S.; Guofang, C.; Chen, Z. Silver nanoparticles: Synthesis, properties, and therapeutic applications. Drug Discov. Today 2015, 20, 595-601. [CrossRef] [PubMed]

9. Nazem, A.; Mansoori, G.A. Diagnostic methods and therapeutic agents. J. Alzheimer's Dis. 2008, 13, $199-223$. [CrossRef] 
10. Foldbjerg, R.; Anh, D.; Herman, D. Cytotoxicity and genotoxicity of silver nanoparticles in the human lung cancer cell line, A549. Arch. Toxicol. 2011, 85, 743-750. [CrossRef]

11. Lee, H.A.; Castro-Aceituno, V.; Abbai, R.; Soo, S.; Kim, Y.; Simu, S.Y.; Yang, D.C.; Lee, H.A.; Yang, D.C. Rhizome of anemarrhena asphodeloides as mediators of the eco-friendly synthesis of silver and gold spherical, face-centred cubic nanocrystals and its anti-migratory and cytotoxic potential in normal and cancer cell lines. Artif. Cellsnanomed. Biotechnol. 2018, 46 (Suppl. 2), 285-294. [CrossRef]

12. Azeez, L.; Lateef, A.; Adebisi, S.A. Silver nanoparticles (AgNPs) biosynthesized using pod extract of Cola nitida enhances antioxidant activity and phytochemical composition of Amaranthus caudatus Linn. Appl. Nanosci. 2017, 7, 59-66. [CrossRef]

13. Li, Z.; Jiang, H.; Xu, C.; Gu, L. Food Hydrocolloids A review: Using nanoparticles to enhance absorption and bioavailability of phenolic phytochemicals. Food Hydrocoll. 2015, 43, 153-164. [CrossRef]

14. Apak, R.; Özyürek, M.; Güçlü, K.; Çapanołlu, E. Antioxidant activity/capacity measurement. 1. Classification, physicochemical principles, mechanisms, and electron transfer (ET)-based assays. J. Agric. Food Chem. 2016, 64, 997-1027. [CrossRef]

15. Greguška, O. Kyslíkové radikály, oxid dusnatý a antioxidačný systém v kĺboch postihnutých zápalom. Rheumatologia 1997, 11, 161-166.

16. Hayyan, M.; Hashim, M.A.; Alnashef, I.M. Superoxide Ion: Generation and chemical implications. Chem. Rev. 2016, 116, 3029-3085. [CrossRef] [PubMed]

17. Durackova, Z. Some current insights into oxidative stress. Physiol. Res. 2010, 59, 459-469.

18. Su, J.; Groves, J.T. Mechanisms of peroxynitrite interactions with heme proteins. Inorg. Chem. 2010, 49, 6317-6329. [CrossRef]

19. Fridovich, I. The biology of oxygen radicals. Science 1978, 201, 875-880. [CrossRef]

20. Förstermann, U. Nitric oxide and oxidative stress in vascular disease. Eur. J. Physiol. 2010, 459, 923-939. [CrossRef]

21. Voetsch, B.; Jin, R.C.; Loscalzo, J. Nitric oxide insufficiency and atherothrombosis. Histochem. Cell Biol. 2004, 122, 353-367. [CrossRef] [PubMed]

22. Kaysen, G.A.; Eiserich, J.P. The role of oxidative stress - Altered lipoprotein structure and function and microinflammation on cardiovascular risk in patients with minor renal dysfunction. J. Am. Soc. Nephrol. 2004, 15, 538-548. [CrossRef] [PubMed]

23. Del, D.; Stewart, A.J.; Pellegrini, N. A review of recent studies on malondialdehyde as toxic molecule and biological marker of oxidative stress. Nutr. Metab. Cardiovasc. Dis. 2005, 15, 316-328. [CrossRef] [PubMed]

24. Viner, R.I.; Hmmer, A.F.R.; Bigelow, D.J.; Schoneich, C. The Oxidative Inactivation of sarcoplasmic reticulum Ca2'-ATPase by peroxynitrite. Free Radic. Res. 1996, 24, 243-259. [CrossRef] [PubMed]

25. Cooke, M.S.; Evans, M.D.; Dizdaroglu, M.; Lunec, J. Oxidative DNA damage: Mechanisms, mutation, and disease. FASEB J. 2003, 17, 1195-1214. [CrossRef] [PubMed]

26. Phaniendra, A.; Babu, D. Free Radicals: Properties, sources, targets, and their implication in various diseases. Ind J Clin. Biochem 2015, 30, 11-26. [CrossRef] [PubMed]

27. Nazem, A.; Mansoori, G.A. Nanotechnology solutions for alzheimer 's disease: Advances in research tools, diagnostic methods and therapeutic agents. J. Alzheimer's Dis. 2020, 13, 199-223. [CrossRef] [PubMed]

28. Ghaffari, S. Oxidative stress in the regulation of normal and neoplastic hematopoiesis. Antioxid. Redox Signaming 2008, 10, 1923-1940. [CrossRef]

29. Klaunig, J.E.; Kamendulis, L.M. The role of oxidative stress in carcinogenesis. Annu Rev Pharm. Toxicol 2004, 44, 239-267. [CrossRef]

30. Katta, R.; Brown, D.N. Diet and skin cancer: The potential role of dietary antioxidants in nonmelanoma skin cancer prevention. J. Ski. Cancer 2015, 2015, 1-10. [CrossRef]

31. Dvor, M.; Igor, S. Urinary catecholamines in children with attention deficit hyperactivity disorder (ADHD): Modulation by a polyphenolic extract from pine bark. Nutr. Neurosci. 2007, 10, 151-157. [CrossRef]

32. Bitanihirwe, B.K.Y.; Woo, T.W. Neuroscience and Biobehavioral Reviews Oxidative stress in schizophrenia: An integrated approach. Neurosci. Biobehav. Rev. 2011, 35, 878-893. [CrossRef]

33. Limbach, L.K.; Wick, P.; Manser, P.; Grass, R.N. Exposure of engineered nanoparticles to human lung epithelial cells: Influence of chemical composition and catalytic activity on oxidative stress. Environ. Sci.Technol. 2007, 41, 4158-4163. [CrossRef] [PubMed] 
34. Akter, M.; Sikder, T.; Rahman, M.; Ullah, A.K.M.A.; Fatima, K.; Hossain, B.; Banik, S.; Hosokawa, T.; Saito, T.; Kurasaki, M. A systematic review on silver nanoparticles-induced cytotoxicity: Physicochemical properties and perspectives. J. Adv. Res. 2018, 9, 1-16. [CrossRef]

35. Jing, M.; Ah, K.; Kyung, I.; Sun, H.; Kim, S.; Yun, J.; Choi, J.; Won, J. Silver nanoparticles induce oxidative cell damage in human liver cells through inhibition of reduced glutathione and induction of mitochondria-involved apoptosis. Toxicol. Lett. 2011, 201, 92-100. [CrossRef]

36. Babior, B.M. Phagocytes and oxidative stress. Physiol. Med. 2000, 109, 33-44. [CrossRef]

37. Halliwell, B.; Gutteridge, J.M.C. Free Raadicals in Biology and Medicine, 5th ed.; Oxford University Press: Oxford, UK, 2015; ISBN 978-0-19-871747-8.

38. Cillard, J.; Cillard, P.; Cormier, M. Effect of experimental factors on the prooxidant behavior of $\alpha$-tocopherol. J. Am. Oil Chem. Soc. 1980, 57, 255-261. [CrossRef]

39. Halliwell, B. Antioxidants and human disease: A general introduction. Nutr. Rev. 1997, 55, 44-49. [CrossRef]

40. Harman, D. Aging: A theory based on free radical and radiation chemistry. J. Gerontol. 1956, 11, $298-300$. [CrossRef]

41. Cao, G.; Prior, R.L. Comparison of different analytical methods for assessing total antioxidant capacity of human serum. Clin. Chem. 1998, 44, 1309-1315. [CrossRef]

42. Floegel, A.; Kim, D.; Chung, S.; Song, W.O.N.O.; Fernandez, M.L.U.Z.; Bruno, R.S.; Koo, S.I.; Chun, O.C.K.K. Development and validation of an algorithm to establish a total antioxidant capacity database of the US diet. Int. J. Food Sci. Nutr. 2010, 61, 600-623. [CrossRef] [PubMed]

43. Floegel, A.; Kim, D.; Chung, S.; Koo, S.I.; Chun, O.K. Comparison of ABTS/DPPH assays to measure antioxidant capacity in popular antioxidant-rich US foods. J. Food Compos. Anal. 2011, 24, 1043-1048. [CrossRef]

44. Pisoschi, A.M.; Negulescu, G.P. Methods for total antioxidant activity determination: A review. Biochem. Anal. Biochem. 2011, 1, 1-10. [CrossRef]

45. Magalhaes, L.M.; Segundo, M.A.; Reis, S.; Lima, J.L.F.C. Methodological aspects about in vitro evaluation of antioxidant properties. Anal. Chim. Acta 2008, 613, 1-19. [CrossRef]

46. Agbor, G.; Vinson, J. Folin-ciocalteau reagent for polyphenolic assay. Int. J. Food Sci. Nutr. Diet. 2014, 3, 1-19. [CrossRef]

47. Arteaga, J.F.; Ruiz-Montoya, M.; Palma, A.; Alonso-Garrido, G.; Pintado, S.; Rodriguez-Mellado, J.M. Comparison of the simple cyclic voltammetry $(\mathrm{CV})$ and DPPH assays for the determination of antioxidant capacity of active principles. Molecules 2012, 17, 5126-5138. [CrossRef]

48. Kedare, S.B.; Singh, R.P. Genesis and development of DPPH method of antioxidant assay. J. Food Sci. Technol. 2011, 48, 412-422. [CrossRef]

49. Sánchez-Moreno, C.; Larrauri, J.A.; Saura-Calixto, F. A procedure to measure the antiradical efficienc y of polyphenols. J Sci Food Agric 1998, 76, 270-276. [CrossRef]

50. Arnao, M.B. Some methodological problems in the determination of antioxidant activity using chromogen radicals: A practical case. Trends Food Sci. Technol. 2000, 11, 419-421. [CrossRef]

51. Re, R.; Pellegrini, N.; Proteggente, A.; Yang, M.; Rice-Evans, C. Antioxidant activity applying an improved ABTS radical cation decolorization assay. Free Radic. Biol. Med. 1999, 26, 1231-1237. [CrossRef]

52. Miller, N.J.; Sampson, J.; Candeias, L.P.; Bramley, P.M.; Rice-evans, C.A. Antioxidant activities of carotenes and xanthophylls. Febs Lett. 1996, 384, 240-242. [CrossRef]

53. Henriquez, C.; Aliaga, C.; Lissi, E. Formation and decay of the ABTS derived radical cation: A comparison of different preparation procedures. Int. J. Chem. Kinet. 2002, 34, 659-665. [CrossRef]

54. Huang, D.; Ou, B.; Prior, R.L. The chemistry behind antioxidant capacity assays. J. Agric. Food Chem. 2005, 53, 1841-1856. [CrossRef] [PubMed]

55. Ilyasov, I.R.; Beloborodov, V.L.; Selivanova, I.A.; Terekhov, R.P. ABTS/PP Decolorization assay of antioxidant capacity reaction pathways. Int. J. Mol. Sci. Rev. 2020, 21, 1131. [CrossRef]

56. Fogliano, V.; Verde, V.; Randazzo, G.; Ritieni, A. method for measuring antioxidant activity and its application to monitoring the antioxidant capacity of wines. J. Agric. Food Chem. 1999, 47, 1035-1040. [CrossRef]

57. Çekiç, S.D.; Avan, A.N.; Uzunboy, S.; Apak, R. A colourimetric sensor for the simultaneous determination of oxidative status and antioxidant activity on the same membrane: $N, N$-dimethyl- $p$-phenylene diamine (DMPD) on Nafion. Anal. Chim. Acta 2015, 865, 60-70. [CrossRef]

58. Folin, O.; Ciocalteau, V. On tyrosine and tryptophane in proteins. J. Biol. Chem. 1927, 73, 627-650. 
59. Singleton, V.L.; Orthofer, R.; Lamuela-Raventós, R.M. Analysis of total phenols and other oxidation substrates and antioxidants by means of folin-ciocalteu reagent. Methods Enzym. 1999, 299, 152-178.

60. Pulido, R.; Bravo, L.; Saura-calixto, F. Antioxidant activity of dietary polyphenols as determined by a modified ferric reducing/antioxidant power assay. J. Agric. Food Chem. 2000, 44, 3396-3402. [CrossRef]

61. Ou, B.; Huang, D.; Hampsch-Woodill, M.; Flanagan, J.A.; Deemer, E.K. Analysis of antioxidant activities of common vegetables employing oxygen radical absorbance capacity (ORAC) and ferric reducing antioxidant power (FRAP) assays. J. Agric. Food Chem. 2002, 50, 3122-3128. [CrossRef]

62. Denev, P.; Ciz, M.; Ambrozova, G.; Lojek, A.; Yanakieva, I.; Kratchanova, M. Solid-phase extraction of berries' anthocyanins and evaluation of their antioxidative properties. Food Chem. 2010, 123, 1055-1061. [CrossRef]

63. Amorati, R.; Valgimigli, L. Advantages and limitations of common testing methods for antioxidants advantages and limitations of common testing methods for antioxidants. Free Radic. Res. 2015, 49, 633-649. [CrossRef]

64. Spickett, C.M.; Wiswedel, I.; Siems, W.; Zarkovic, K.; Zarkovic, N. Advances in methods for the determination of biologically relevant lipid peroxidation products. Free Radic. Res. 2010, 44, 1172-1202. [CrossRef] [PubMed]

65. Nagaoka, S.; Nagai, K.; Fujii, Y.; Ouchi, A.; Mukai, K. Development of a new free radical absorption capacity assay method for antioxidants: Aroxyl radical absorption capacity (ARAC). J. Agric. Food Chem. 2013, 61, 10054-10062. [CrossRef] [PubMed]

66. Schwarz, K.; Bertelsen, G.; Nissen, L.R.; Gardner, P.T.; Heinonen, M.I.; Hopia, A.; Lambelet, T.H.P.; Mcphail, D.; Skibsted, L.H.; Tijburg, L. Investigation of plant extracts for the protection of processed foods against lipid oxidation. Comparison of antioxidant assays based on radical scavenging, lipid oxidation and analysis of the principal antioxidant compounds. Eur. Food Res. Technol. 2001, 212, 319-328. [CrossRef]

67. Pisoschi, A.M.; Cimpeanu, C.; Predoi, G. Electrochemical methods for total antioxidant capacity and its main contributors determination: A review. Open Chem. 2015, 13, 824-856. [CrossRef]

68. Oliveira, G.K.F.; Tormin, T.F.; Sousa, R.M.F.; De Oliveira, A.; De Morais, S.A.L.; Richter, E.M.; Munoz, R.A.A. Batch-injection analysis with amperometric detection of the DPPH radical for evaluation of antioxidant capacity. Food Chem. 2016, 192, 691-697. [CrossRef] [PubMed]

69. Milardović, S.; Ivekovic, D.; Grabaric, B.S. A novel amperometric method for antioxidant activity determination using DPPH free radical. Bioelectrochemistry 2006, 68, 175-180. [CrossRef] [PubMed]

70. Song, J.; Zhao, C.; Guo, W.; Kang, X.; Zhang, J. Theoretical and experimental study of the biamperometry for irreversible redox couple in flow system. Anal. Chim. Acta 2002, 470, 229-240. [CrossRef]

71. Yan, R.; Cao, Y.; Yang, B. HPLC-DPPH screening method for evaluation of antioxidant compounds extracted from semen oroxyli. Molecules 2014, 19, 4409-4417. [CrossRef] [PubMed]

72. Pedan, V.; Fischer, N.; Rohn, S. An online NP-HPLC-DPPH method for the determination of the antioxidant activity of condensed polyphenols in cocoa. FRIN 2016, 89, 890-900. [CrossRef]

73. Stalmach, A.; Mullen, W.; Nagai, C.; Crozier, A. On-line HPLC analysis of the antioxidant activity of phenolic compounds in brewed, paper-filtered coffee. Braz. J. Plant Physiol. 2006, 18, 253-262. [CrossRef]

74. Mello, L.D.; Kubota, L.T. Review of the use of biosensors as analytical tools in the food and drink industries. Food Chem. 2002, 77, 237-256. [CrossRef]

75. Mello, L.D.; Kubota, L.T. Biosensors as a tool for the antioxidant status evaluation. Talanta 2007, 72, 335-348. [CrossRef] [PubMed]

76. Sherry, L.J.; Chang, S.-H.H.; Schatz, G.C.; Van Duyne, R.P.; Wiley, B.J.; Xia, Y. Localized surface plasmon resonance spectroscopy of single silver nanocubes. Nano Lett. 2005, 5, 2034-2038. [CrossRef]

77. Amendola, V.; Bakr, O.M.; Stellacci, F. A study of the surface plasmon resonance of silver nanoparticles by the discrete dipole approximation method: Effect of shape, size, structure, and assembly. Plasmonics 2010, 5, 85-97. [CrossRef]

78. Anker, J.N.; Hall, W.P.; Lyandres, O.; Shah, N.C.; Zhao, J.; VanDuyne, R.P. Biosensing with plasmonic nanosensors. Nat. Mater. 2008, 7, 8-10. [CrossRef]

79. Vilela, D.; González, M.C.; Escarpa, A. Nanoparticles as analytical tools for in-vitro antioxidant-capacity assessment and beyond. Trends Anal. Chem. 2015, 64,1-16. [CrossRef]

80. Baláž, M.; Bedlovičová, Z.; Kováčová, M.; Balážová, Ĺ.; Salayová, A. Green and bio-mechanochemical approach to silver nanoparticles synthesis, characterization and antibacterial potential Matej. In Nanostructures for Antimicrobial and Antibio Im Applications; Prasad, R., Siddhardha, B., Dyavaiah, M., Eds.; Springer Nature: Cham, Switzerland, 2020; pp. 145-183. ISBN 9783030403362. 
81. Kowshik, M.; Deshmukh, N.; Vogel, W.; Urban, J.; Kulkarni, S.K.; Paknikar, K.M. Microbial synthesis of semiconductor CdS nanoparticles, their characterization, and their use in the fabrication of an ideal diode. Biotechnol. Bioeng. 2002, 78, 583-588. [CrossRef]

82. Zhang, X.-F.; Liu, Z.-G.; Shen, W.; Gurunathan, S. Silver nanoparticles: Synthesis, characterization, properties, applications, and therapeutic approaches. Int. J. Mol. Sci. 2016, 17, 1534. [CrossRef]

83. Gurav, A.S.; Kodas, T.T.; Wang, L.-M.; Kauppinen, E.I.; Joutsensaari, J. Generation of nanometer-size fullerene particles via vapor condensation. Chem. Phys. Lett. 1994, 218, 304-308. [CrossRef]

84. Pluym, T.C.; Powell, Q.H.; Gurav, A.S.; Ward, T.L.; Kodas, T.T.; Wang, L.M.; Glicksman, H.D. Solid silver particle production by spray pyrolysis. J. Aerosol Sci. 1993, 24, 383-392. [CrossRef]

85. Lee, D.K.; Kang, Y.S. Synthesis of silver nanocrystallites by a new thermal decomposition method and their characterization. Etri J. 2004, 26, 252-256. [CrossRef]

86. Baláž, M.; Daneu, N.; Balážová, L'.; Dutková, E.; Tkáčiková, L'.; Briančin, J.; Vargová, M.; Balážová, M.; Zorkovská, A.; Baláž, P. Bio-mechanochemical synthesis of silver nanoparticles with antibacterial activity. Adv. Powder Technol. 2017, 28, 3307-3312. [CrossRef]

87. Hernández, J.G.; Halasz, I.; Crawford, D.E.; Krupička, M.; Baláž, M.; André, V.; Vella-Zarb, L.; Niidu, A.; García, F.; Maini, L.; et al. European research in focus: Mechanochemistry for sustainable industry (COST Action MechSustInd). Eur. J. Org. Chem. 2020, 8-9. [CrossRef]

88. Baláž, P.; Achimovicová, M.; Baláž, M.; Billik, P.; Zara, C.Z.; Criado, J.M.; Delogu, F.; Dutková, E.; Gaffet, E.; Gotor, F.J.; et al. Hallmarks of mechanochemistry: From nanoparticles to technology. Chem. Soc. Rev. 2013, 42, 7571-7637. [CrossRef] [PubMed]

89. Tan, D.; García, F. Main group mechanochemistry: From curiosity to established protocols. Chem. Soc. Rev. 2019, 48, 2274-2292. [CrossRef] [PubMed]

90. Bychkov, A.; Podgorbunskikh, E.; Bychkova, E.; Lomovsky, O. Current achievements in the mechanically pretreated conversion of plant biomass. Biotechnol. Bioeng. 2019, 116, 1231-1244. [CrossRef]

91. Do, J.-L.; Friščić, T. Mechanochemistry: A force of synthesis. Acs Cent. Sci. 2017, 3, 13-19. [CrossRef] [PubMed]

92. Szczęśniak, B.; Borysiuk, S.; Choma, J.; Jaroniec, M. Mechanochemical synthesis of highly porous materials. Mater. Horiz. 2020, 7, 1457-1473. [CrossRef]

93. Xu, C.; Paone, E.; Rodriguez-Pardón, D.; Luque, R.; Mauriello, F. Recent catalytic routes for the preparation and the upgrading of biomass derived furfural. Chem. Soc. Rev. 2020. [CrossRef]

94. Evanoff, D.D.; Chumanov, G. Size-controlled synthesis of nanoparticles. 2. measurement of extinction, scattering, and absorption cross sections. J. Phys. Chem. B 2004, 108, 13957-13962. [CrossRef]

95. Chen, S.-F.; Zhang, H. Aggregation kinetics of nanosilver in different water conditions. Adv. Nat. Sci. Nanosci. Nanotechnol. 2012, 3, 035006. [CrossRef]

96. Oliveira, M.M.; Ugarte, D.; Zanchet, D.; Zarbin, A.J.G. Influence of synthetic parameters on the size, structure, and stability of dodecanethiol-stabilized silver nanoparticles. J. Colloid Interface Sci. 2005, 292, 429-435. [CrossRef]

97. Sun, Y.G.; Xia, Y.N. Shape-controlled synthesis of gold and silver nanoparticles. J. Sci. 2002, 298, $2176-2179$. [CrossRef]

98. Marchiol, L.; Mattiello, A.; Pošćić, F.; Giordano, C.; Musetti, R. In vivo synthesis of nanomaterials in plants: Location of silver nanoparticles and plant metabolism. Nanoscale Res. Lett. 2014, 9, 101. [CrossRef] [PubMed]

99. Baláž, M.; Balážová, L'.; Daneu, N.; Dutková, E.; Balážová, M.; Bujňáková, Z.; Shpotyuk, Y. Plant-Mediated Synthesis of silver nanoparticles and their stabilization by wet stirred media milling. Nanoscale Res. Lett. 2017, 12, 1-9. [CrossRef]

100. Gurunathan, S.; Kalishwaralal, K.; Vaidyanathan, R.; Venkataraman, D.; Pandian, S.R.K.; Muniyandi, J.; Hariharan, N.; Eom, S.H. Biosynthesis, purification and characterization of silver nanoparticles using Escherichia coli. Colloids Surf. B Biointerfaces 2009, 74, 328-335. [CrossRef]

101. Pallavicini, P.; Arciola, C.R.; Bertoglio, F.; Curtosi, S.; Dacarro, G.; D’Agostino, A.; Ferrari, F.; Merli, D.; Milanese, C.; Rossi, S.; et al. Silver nanoparticles synthesized and coated with pectin: An ideal compromise for anti-bacterial and anti-biofilm action combined with wound-healing properties. J. Colloid Interface Sci. 2017, 498, 271-281. [CrossRef] [PubMed] 
102. Ahmed, S.; Ahmad, M.; Swami, B.L.; Ikram, S. A review on plants extract mediated synthesis of silver nanoparticles for antimicrobial applications: A green expertise. J. Adv. Res. 2016, 7, 17-28. [CrossRef] [PubMed]

103. Mittal, A.K.; Chisti, Y.; Banerjee, U.C. Synthesis of metallic nanoparticles using plant extracts. Biotechnol. Adv. 2013, 31, 346-356. [CrossRef]

104. Kharissova, O.V.; Dias, H.V.R.; Kharisov, B.I.; Pérez, B.O.; Pérez, V.M.J. The greener synthesis of nanoparticles. Trends Biotechnol. 2013, 31, 240-248. [CrossRef]

105. Al-Bahrani, R.; Raman, J.; Lakshmanan, H.; Hassan, A.A.; Sabaratnam, V. Green synthesis of silver nanoparticles using tree oyster mushroom Pleurotus ostreatus and its inhibitory activity against pathogenic bacteria. Mater. Lett. 2017, 186, 21-25. [CrossRef]

106. Gurunathan, S.; Raman, J.; Abd Malek, S.N.; John, P.A.; Vikineswary, S. Green synthesis of silver nanoparticles using Ganoderma neo-japonicum Imazeki: A potential cytotoxic agent against breast cancer cells. Int. J. Nanomed. 2013, 8, 4399-4413. [CrossRef]

107. Bhat, R.; Deshpande, R.; Ganachari, S.V.; Huh, D.S.; Venkataraman, A. Photo-irradiated biosynthesis of silver nanoparticles using edible mushroom Pleurotus florida and their antibacterial activity studies. Bioinorg. Chem. Appl. 2011, 2011, 1-7. [CrossRef] [PubMed]

108. Saifuddin, N.; Wong, C.W.; Yasumira, a.a.N.; Nur Yasumira, A.A. Rapid biosynthesis of silver nanoparticles using culture supernatant of bacteria with microwave irradiation. E-J. Chem. 2009, 6, 61-70. [CrossRef]

109. Shaligram, N.S.; Bule, M.; Bhambure, R.; Singhal, R.S.; Singh, S.K.; Szakacs, G.; Pandey, A. Biosynthesis of silver nanoparticles using aqueous extract from the compactin producing fungal strain. Process Biochem. 2009, 44, 939-943. [CrossRef]

110. Nanda, A.; Saravanan, M. Biosynthesis of silver nanoparticles from Staphylococcus aureus and its antimicrobial activity against MRSA and MRSE. Nanomed. Nanotechnol. Biol. Med. 2009, 5, 452-456. [CrossRef]

111. Binupriya, A.R.; Sathishkumar, M.; Yun, S. Il Myco-crystallization of silver ions to nanosized particles by live and dead cell filtrates of aspergillus oryzae var. viridis and its bactericidal activity toward staphylococcus aureus KCCM 12256. Ind. Eng. Chem. Res. 2010, 49, 852-858. [CrossRef]

112. Khamhaengpol, A.; Siri, S. Green synthesis of silver nanoparticles using tissue extract of weaver ant larvae. Mater. Lett. 2017, 192, 72-75. [CrossRef]

113. Rajeshkumar, S.; Malarkodi, C.; Paulkumar, K.; Vanaja, M.; Gnanajobitha, G.; Annadurai, G. Algae mediated green fabrication of silver nanoparticles and examination of its antifungal activity against clinical pathogens. Int. J. Met. 2014, 2014, 1-8. [CrossRef]

114. Thanighaiarassu, R.R.; Nambikkairaj, B.; Devika, R.; Raghunathan, D.; Manivannan, N.; Sivamani, P.; Nadu, T. Biological greenish nanosynthesis of silver nanoparticle using plant leaf essential oil compound farnesol and their antifungal activity against human pathogenic fungi. Worldj. Pharm. Res. 2015, 4, 1706-1717.

115. Raveendran, P.; Fu, J.; Wallen, S.L. A simple and 'green' method for the synthesis of Au, Ag, and Au-Ag alloy nanoparticles. Green Chem. 2006, 8, 34-38. [CrossRef]

116. Vigneshwaran, N.; Nachane, R.P.; Balasubramanya, R.H.; Varadarajan, P.V. A novel one-pot 'green' synthesis of stable silver nanoparticles using soluble starch. Carbohydr. Res. 2006, 341, 2012-2018. [CrossRef] [PubMed]

117. Konował, E.; Sybis, M.; Modrzejewska-Sikorska, A.; Milczarek, G. Synthesis of dextrin-stabilized colloidal silver nanoparticles and their application as modifiers of cement mortar. Int. J. Biol. Macromol. 2017, 104, 165-172. [CrossRef] [PubMed]

118. Pivec, T.; Hribernik, S.; Kolar, M.; Kleinschek, K.S. Environmentally friendly procedure for in-situ coating of regenerated cellulose fibres with silver nanoparticles. Carbohydr. Polym. 2017, 163, 92-100. [CrossRef]

119. Gardea-Torresdey, J.L.; Gomez, E.; Peralta-Videa, J.R.; Parsons, J.G.; Troiani, H.; Jose-Yacaman, M. Alfalfa sprouts: A natural source for the synthesis of silver nanoparticles. Langmuir 2003, 19, 1357-1361. [CrossRef]

120. Deljou, A.; Goudarzi, S. Green extracellular synthesis of the silver nanoparticles using thermophilic bacillus Sp. AZ1 and its antimicrobial activity against several human pathogenetic bacteria. Iran J Biotech 2016, 14, 1-8. [CrossRef] [PubMed]

121. Singh, H.; Du, J.; Singh, P.; Hoo, T. Extracellular synthesis of silver nanoparticles by Pseudomonas sp. THG-LS1. 4 and their antimicrobial application. J. Pharm. Anal. 2018, 8, 258-264. [CrossRef]

122. Prakash, A.; Sharma, S.; Ahmad, N.; Ghosh, A.; Sinha, P. Synthesis of AgNPs by bacillus cereus bacteria and their antimicrobial potential. J. Biomater. Nanotechnol. 2011, 2, 156-162. [CrossRef] 
123. Gudikandula, K.; Vadapally, P.; Charya, M.A.S. Biogenic synthesis of silver nanoparticles from white rot fungi: Their characterization and antibacterial studies. OpenNano 2017, 2, 64-78. [CrossRef]

124. Xixi, Z.; Liangfu, Z.; Rajoka, R.; Shahid, M.; Lu, Y.; Chunmei, J.; Dongyan, S.; Jing, Z.; Junling, S.; Qingsheng, H.; et al. Fungal silver nanoparticles: Synthesis, application and challenges. Crit. Rev. Biotechnol. 2017, 38, 1-19. [CrossRef]

125. Ahn, E.-Y.; Jin, H.; Park, Y. Assessing the antioxidant, cytotoxic, apoptotic and wound healing properties of silver nanoparticles green-synthesized by plant extracts. Mater. Sci. Eng. C 2019, 101, 204-216. [CrossRef]

126. Khorrami, S.; Zarrabi, A.; Khaleghi, M.; Danaei, M.; Mozfari, M. Selective cytotoxicity of green synthesized silver nanoparticles against the MCF-7 tumor cell line and their enhanced antioxidant and antimicrobial properties. Int. J. Nanomed. 2018, 13, 8013-8024. [CrossRef]

127. Demirbas, A.; Welt, B.A.; Ocsoy, I. Biosynthesis of red cabbage extract directed Ag NPs and their effect on the loss of antioxidant activity. Mater. Lett. 2016, 179, 20-23. [CrossRef]

128. Öztürk, F.; Ço, S.; Duman, F. Biosynthesis of silver nanoparticles using leaf extract of Aesculus hippocastanum (horse chestnut): Evaluation of their antibacterial, antioxidant and drug release system activities. Mater. Sci. Eng. C J. 2020, 107, 1-11. [CrossRef]

129. Elemike, E.E.; Fayemi, O.E.; Ekennia, A.C.; Onwudiwe, D.C.; Ebenso, E.E. Silver nanoparticles mediated by Costus afer leaf electrochemical properties. Molecules 2017, 22. [CrossRef]

130. Ijayan, R.; Joseph, S.; Mathew, B. Indigofera tinctoria leaf extract mediated green synthesis of silver and gold nanoparticles and assessment of their anticancer, antimicrobial, antioxidant and catalytic properties. Artif. Cellsnanomed. Biotechnol. 2018, 46, 861-871. [CrossRef] [PubMed]

131. Chinnasamy, G.; Chandrasekharan, S.; Bhatnagar, S. Biosynthesis of silver nanoparticles from Melia azedarach: Enhancement of antibacterial, wound healing, antidiabetic and antioxidant activities. Int. J. Nanomed. 2019, 14, 9823-9836. [CrossRef]

132. Khan, S.A.; Shahid, S.; Lee, C. Green synthesis of gold and silver nanoparticles using leaf extract of clerodendrum inerme; characterization, antimicrobial, and antioxidant activities. Biomolecules 2020, 10, 835. [CrossRef]

133. Mittal, A.K.; Kaler, A.; Banerjee, U.C. Free radical scavenging and antioxidant activity of silver nanoparticles synthesized from flower extract of rhododendron dauricum. Nano Biomed Eng 2012, 4, 118-124. [CrossRef]

134. Kumar, D.; Arora, S.; Danish, M. Plant based synthesis of silver nanoparticles from ougeinia oojeinensis leaves extract and their membrane stabilizing, antioxidant and antimicrobial activities. Mater. Today Proc. 2019, 17, 313-320. [CrossRef]

135. Phull, A.; Abbas, Q.; Ali, A.; Raza, H.; Ja, S.; Zia, M.; Haq, I. Antioxidant, cytotoxic and antimicrobial activities of green synthesized silver nanoparticles from crude extract of Bergenia ciliata. Futur. J. Pharm. Sci. 2016, 2, 31-36. [CrossRef]

136. Salari, S.; Esmaeilzadeh, S.; Samzadeh-kermani, A.; Yosefzaei, F. In-vitro evaluation of antioxidant and antibacterial potential of green synthesized silver nanoparticles using prosopis farcta fruit extract. Iran. J. Pharm. Res. 2019, 18, 430-445.

137. Priya, R.S.; Geetha, D.; Ramesh, P.S. Ecotoxicology and environmental safety antioxidant activity of chemically synthesized AgNPs and biosynthesized pongamia pinnata leaf extract mediated AgNPs - A comparative study. Ecotoxicol. Environ. Saf. 2016, 134, 308-318. [CrossRef] [PubMed]

138. Valsalam, S.; Agastian, P.; Valan, M.; Al-dhabi, N.A.; Ghilan, A.M.; Kaviyarasu, K.; Ravindran, B. Biology rapid biosynthesis and characterization of silver nanoparticles from the leaf extract of tropaeolum majus L. and its enhanced in-vitro antibacterial, antifungal, antioxidant and anticancer properties. J. Photochem. Photobiol. B Biol. 2019, 191, 65-74. [CrossRef] [PubMed]

139. Khoshnamvand, M.; Huo, C.; Liu, J. Silver nanoparticles synthesized using allium ampeloprasum L. leaf extract: Characterization and performance in catalytic reduction of 4-nitrophenol and antioxidant activity. J. Mol. Struct. 2019, 1175, 90-96. [CrossRef]

140. Das, G.; Patra, J.K.; Basavegowda, N.; Vishnuprasad, C.N.; Shin, H. Comparative study on antidiabetic, cytotoxicity, antioxidant and antibacterial properties of biosynthesized silver nanoparticles using outer peels of two varieties of Ipomoea batatas (L.) Lam. Int. J. Nanomed. 2019, 14, 4741-4754. [CrossRef] [PubMed]

141. Otunola, G.A.; Afolayan, A.J.; Ajayi, E.O.; Odeyemi, S.W. Characterization, antibacterial and antioxidant properties of silver nanoparticles synthesized from aqueous extracts of allium sativum, zingiber officinale, and capsicum frutescens. Pharm. Mag. 2017, 13, 5201-5208. [CrossRef] 
142. Saratale, R.G.; Benelli, G.; Kumar, G.; Kim, D.S.; Saratale, G.D. Bio-fabrication of silver nanoparticles using the leaf extract of an ancient herbal medicine, dandelion (Taraxacum officinale), evaluation of their antioxidant, anticancer potential, and antimicrobial activity against phytopathogens. Environ. Sci. Pollut. Res. Int. 2018, 25, 10392-10406. [CrossRef]

143. Ashraf, J.M.; Ansari, M.A.; Khan, H.M.; Alzohairy, M.A.; Choi, I. Green synthesis of silver nanoparticles and characterization of their inhibitory effects on AGEs formation using biophysical techniques. Sci. Rep. 2016, 6, 20414. [CrossRef]

144. Sharifi-Rad, M.; Pohl, P. Synthesis of biogenic silver nanoparticles ( AgCl-NPs ) using a pulicaria vulgaris gaertn. Aerial part extract and their application as antibacterial, antifungal and antioxidant agents. Nanomaterials 2020, 10, 638. [CrossRef]

145. Sathiyaseelan, A.; Saravanakumar, K.; Vijaya, A.; Mariadoss, A.; Wang, M. International journal of biological macromolecules biocompatible fungal chitosan encapsulated phytogenic silver nanoparticles enhanced antidiabetic, antioxidant and antibacterial activity. Int. J. Biol. Macromol. 2020, 153, 63-71. [CrossRef]

146. Rajput, S.; Kumar, D.; Agrawal, V. Green synthesis of silver nanoparticles using Indian Belladonna extract and their potential antioxidant, anti-inflammatory, anticancer and larvicidal activities. Plant Cell Rep. 2020. [CrossRef]

147. Selvan, D.A.; Mahendiran, D.; Kumar, R.S.; Rahiman, A.K. Garlic, green tea and turmeric extracts-mediated green synthesis of silver nanoparticles: Phytochemical, antioxidant and in vitro cytotoxicity studies. J. Photochem. Photobiol. B Biol. 2018, 180, 243-252. [CrossRef]

148. Wang, L.; Wu, Y.; Xie, J.; Wu, S.; Wu, Z. Characterization, antioxidant and antimicrobial activities of green synthesized silver nanoparticles from Psidium guajava L. leaf aqueous extracts. Mater. Sci. Eng. C 2018, 86, 1-8. [CrossRef] [PubMed]

149. Journal, A.I.; Johnson, P.; Krishnan, V.; Loganathan, C.; Govindhan, K.; Raji, V.; Sakayanathan, P.; Vijayan, S.; Palvannan, T. Rapid biosynthesis of Bauhinia variegata flower extract-mediated silver nanoparticles: An effective antioxidant scavenger and $\alpha$-amylase inhibitor. Artif. Cellsnanomed. Biotechnol. 2018, 46, 1488-1494. [CrossRef]

150. Yousaf, H.; Mehmood, A.; Shafique, K.; Raffi, M. Green synthesis of silver nanoparticles and their applications as an alternative antibacterial and antioxidant agents. Mater. Sci. Eng. C 2020, 112, 1-7. [CrossRef]

151. Mousavi-Khattat, M.; Keyhanfar, M.; Razmjou, A. A comparative study of stability, antioxidant, DNA cleavage and antibacterial activities of green and chemically synthesized silver nanoparticles. Artif. Cellsnanomed. Biotechnol. 2018, 46, 1022-1031. [CrossRef] [PubMed]

152. Rajkumar, T.; Sapi, A.; Das, G.; Debnath, T.; Ansari, A. Biosynthesis of silver nanoparticle using extract of Zea mays (corn flour) and investigation of its cytotoxicity effect and radical scavenging potential. J. Photochem. Photobiol. B Biol. 2019, 193, 1-7. [CrossRef] [PubMed]

153. Vilas, V.; Philip, D.; Mathew, J. Essential oil mediated synthesis of silver nanocrystals for environmental, anti-microbial and antioxidant applications. Mater. Sci. Eng. C 2016, 61, 429-436. [CrossRef]

154. González-ballesteros, N.; Rodríguez-argüelles, M.C.; Prado-lópez, S.; Lastra, M.; Grimaldi, M.; Cavazza, A.; Nasi, L.; Salviati, G. Macroalgae to nanoparticles: Study of Ulva lactuca L. role in biosynthesis of gold and silver nanoparticles and of their cytotoxicity on colon cancer cell lines. Mater. Sci. Eng. C 2019, 97, 498-509. [CrossRef]

155. Saravanakumar, K.; Wang, M. Microbial Pathogenesis Trichoderma based synthesis of anti-pathogenic silver nanoparticles and their characterization, antioxidant and cytotoxicity properties. Microb. Pthogenes. 2018, 114, 269-273. [CrossRef]

156. Shahid, M.; Rajoka, R.; Mahreen, H.; Zhang, H.; Zhao, L.; He, Z. Antibacterial and antioxidant activity of exopolysaccharide mediated silver nanoparticle synthesized by Lactobacillus brevis isolated from Chinese koumiss. Colloids Surf. B Biointerfaces 2020, 186, 1-11. [CrossRef]

157. Sivasankar, P.; Seedevi, P.; Poongodi, S. Characterization, antimicrobial and antioxidant property of exopolysaccharide mediated silver nanoparticles synthesized by Streptomyces violaceus MM72. Carbohydr. Polym. 2018, 181, 752-759. [CrossRef]

158. Gahlawat, G.; Shikha, S.; Chaddha, B.S.; Chaudhuri, S.R.; Mayilraj, S. Microbial glycolipoprotein-capped silver nanoparticles as emerging antibacterial agents against cholera. Microb. Cell Fact. 2016, 15, 1-14. [CrossRef] [PubMed] 
159. Mittal, A.K.; Bhaumik, J.; Kumar, S.; Banerjee, U.C. Elucidation of prospective mechanism and therapeutic potential. J. Colloid Interface Sci. 2014, 415, 39-47. [CrossRef]

160. Alves, T.F.; Chaud, M.V.; Grotto, D.; Jozala, A.F.; Pandit, R.; Rai, M.; Alves, C. Association of silver nanoparticles and curcumin solid dispersion: Antimicrobial and antioxidant properties. Aaps Pharmscitech 2018, 19, 225-231. [CrossRef] [PubMed]

161. Docea, A.O.; Calina, D.; Buga, A.M.; Zlatian, O.; Popescu, E.L.; Stoica, A.E.; Catalina, A. The effect of silver nanoparticles on antioxidant/pro-oxidant balance in a murine model. Int. J. Mol. Sci. 2020, 21, 1233. [CrossRef] [PubMed]

162. John, T.; Odunayo, O.; Benjakul, S.; Rujiralai, T. Synthesis and characterization of novel poly (3-aminophenyl boronic acid- co-vinyl alcohol) nanocomposite polymer stabilized silver nanoparticles with antibacterial and antioxidant applications. Colloids Surf. B Biointerfaces 2020, 193, 1-10. [CrossRef]

163. Bhutto, A.A.; Kalay, Ş.; Sherazi, S.T.H.; Culha, M. Quantitative structure-activity relationship between antioxidant capacity of phenolic compounds and the plasmonic properties of silver nanoparticles. Talanta 2018, 189, 174-181. [CrossRef]

164. Shanmugasundaram, T.; Radhakrishnan, M.; Gopikrishnan, V. Colloids and Surfaces B: Biointerfaces A study of the bactericidal, anti-biofouling, cytotoxic and antioxidant properties of actinobacterially synthesised silver nanoparticles. Colloids Surf. B Biointerfaces 2013, 111, 680-687. [CrossRef]

(C) 2020 by the authors. Licensee MDPI, Basel, Switzerland. This article is an open access article distributed under the terms and conditions of the Creative Commons Attribution (CC BY) license (http://creativecommons.org/licenses/by/4.0/). 